\title{
Mit liv og mit virke
}

\author{
Af Jørgen Ravn, \\ ved Karen Marie Ravn.
}

Pens. overlærer, tidligere efterskoleforstander Jørgen Ravn døde den 13. maj 1957. Et halvt år forinden havde han fuldført denne levnedsbeskrivelse, som er skrevet i løbet af hans sidste år. Beskrivelsen aftrykkes her væentligt i Jørgen Ravns endelige formulering, dog med undtagelse af nogle afsnit, der er indføjet fra en parallelkladde om tiden frem til 1898.

Jorgen Ravns hensigt med at skrive om sin livsgerning har tydeligt været at give offentligheden sit syn på en historisk periode set fra skolefronten. Selv anforer han, at levnedsbeskrivelsen også er blevet til som kvittering for ridderkorset og ikke mindst af hensyn til hans efterslægt.

K. M. R.

Undertegnede er født den 10. april 1871 i landsbyen Skærup ved hovedlandevejen mellem Vejle og Fredericia; her var min far gårdmand og hed Henrik Sørensen.

Ifølge gammel skik blev hans fornavn i dåben mit efternavn, og jeg kom til at hedde Jørgen Henriksen med slutnavnet Ravn efter en tidligere ejer af gården, der var bedstefar til fars farste kone. Min mor var gårdmandsdatter fra Andkær og tilhørte den på Vejleegnen dengang så udbredte Bjerreslægt; hendes navn var Sidsel Maric Bjerre. Af hendes børneflok, der talte fire drenge og en pige, var jeg den xldste.

1 min tidligste barndom lå jordene endnu hen fra udskiftningen i mange småmarker til hver gård i Skxrup, og skulle de ulemper, som hermed fulgte, forsvinde, kunne dette kun ske ved, at nogle af gårdmændene i den tæt bebyggede landsby kom til at bo på de såkaldte udmarker; men de fleste var groet så fast ved det nære naboskab i byen, at de ikke kunne overvinde sig selv til et sådant flyt. Herpå var forhandlingerne stadigt strandet, indtil min far som den første tilbød at flytte sin gård ud, og der kom nu en sådan gang $i$ forhandlingerne, at de medførte den gode fordeling af jordene i Skærup, som består den dag i dag. Jeg nævner dette for at vise, at far ikke var uden initiativ og ejede megen energi, og begge dele fik han megen brug for, da flyttet ikke blot krævede nye bygninger på laden nær, 


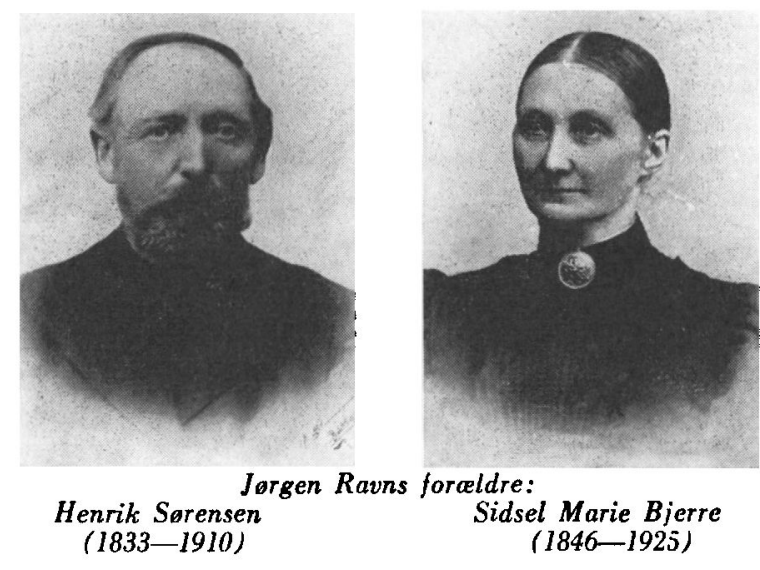

men også mergling og dræning af de gode, men forsømte udmarker, han fik for sin byjord.

Jeg var dengang fem år og er således gennem mine drenge- og første ungdomsår vokset op $\mathrm{i}$ en travl og omfattende virksombed, der sikkert har bidraget sit til, at jeg som skolemand så at sige aldrig gav op over for vanskeligheder; $i$ alt fald var far $i$ dette stykke bestandig mit store forbillede, og dette kom ikke til at høre til sjældenheder på min livsvej.

Mor var far en værdifuld hjælper. Hun forstod ikke blot at holde hus og lave så godt smør i vort såkaldte vandmejeri, at vi fik overpris for det hos vor købmand i Vejle, men hun forstod også at skabe et hjem, som det var godt at vokse op i. I kraft af sit milde sind, sin stærke retfærdighedssans og sin dygtige husførelse blev hun hjemmets midtpunkt. Til hende kom vi børn - også min halvbror - med vore ønsker og sorger og gik som regel trøstet fra hende, selv i de tilfælde, hvor hun hjalp os $\mathrm{i}$ vor modgang ved at finde årsagen hos os selv. Ikke mindre taknemmelig er jeg for, at jeg hos hende allerede $i$ drengeårene mødte hendes levende følelse af, at Gud er virkelighed; jeg mindes endnu mit følgeskab med hende til Skærup kirke og synes at kunne høre hende synge - især Brorsons og Grundtvigs salmer -, når hun arbejdede $\mathrm{i}$ mejeriet.

Efterhånden, som jeg voksede til og begyndte at tænke over min mulige fremtid, meldte der sig en folelse af, at det ikke var landmand, jeg skulle være. Dette var far ked af, og da det omsider lykkedes for 
mig som konfirmeret at komme i Vejle kommunale realskole for at tage præliminæreksamen, gjorde han sit til at anbringe mig så nær landbruget som muligt ved at overtale mig til at blive dyrlæge. Dette havde jeg intet imod, uklar som jeg var over mine egne anlæg.

I Vejle realskole gik det efter den gamle melodi: "Hvad står der i din bog, dreng! « og følgen heraf blev, at undervisningen havde ondt ved at fange elevernes opmærksomhed; timerne var derfor ret urolige, og spanskrøret måtte of te frem.

Imidlertid blev en af min klasses lærere syg og måtte erstattes af en vikar. Drengeflokken glædede sig allerede på forhånd til al den "sjov «, der antagelig kunne drives med en fremmed lærer, men hvilken overraskelse mødte min klasse ikke i ham! Thi før timen endnu var til ende, gav selv de værste spilopmagere op af bare forbavselse over, at en time kunne være så interessant, og mange af os glædede sig allerede til hans følgende timer. Min beundring for ham som lærer steg fra uge til uge, og en skønne dag betroede jeg min mor, at jeg ikke, som far ønskede, ville være dyrlæge, og bad hende hjælpe mig med at få hans tilladelse til at blive lærer.

Det var mors sans for det rette menneskelige og åndelige i tilværelsen, der ved vikarens hjælp havde sejret hos mig ved valget af min fremtidige arbejdsmark.

Efter ca. 11/2 års forløb var jeg gammel nok til at kunne blive optaget på et seminarium, og her kom tilfældet mig atter til hjælp.

En onkel af mig havde i konfirmationsgave foræret mig en jubilæumsbog om Gedved højskole og seminarium, som det havde moret mig at læse. Bogen blev nu taget frem igen, og af den fremgik det, at lærerne ikke blot var skolemestre, men også forkyndere; det var især skolens forstander, P. Bojsen, min interesse samlede sig om, for der var så meget af det, der fortaltes om ham, som mindede mig om vikaren på Vejle realskole. Dette gjorde, at jeg havnede som seminarieelev i Gedved, og det var - synes jeg i dag - min lykke. Højskolen var ganske vist nedlagt, men dens ånd levede videre på seminariet. Bojsens fag var verdenshistorie og pædagogik, og i dem begge var der god plads til ham personlig som udpræget højskolemand; hans fortxlling af verdenshistorie og overvejelser over pædagogiske spørgsmål var både levende og fængslende for mig dengang, men knapt så grundige, som jeg ville forlange i dag.

Når jeg tænker tilbage på den tid, må jeg også især mindes to andre 
af seminariets larere, nemlig den grundige Martin Kristensen for hans timer $i$ litteraturhistorie og hans ypperlige fremstilling af de nordiske sagaer, samt den senere undervisningsminister og seminarieforstander Jens Byskov. Af Byskov lærte jeg gennem hans grundige og interessante undervisning $\mathrm{i}$ regning og senere - privat $-i$ dansk noget af den kunst: skridt for skridt at træenge ind $i$ et vanskeligt spørgsmål. Hans evne til at klarlægge et sådant for os nærede vi alle den største beundring for, og jeg mindes endnu, hvor svært det faldt mig i xldste klasse at søge hans hjælp ved løsningen af de svære regneopgaver, for jeg vidste på forhånd, at jeg ville forlade ham på katederet, skamfuld over, at jeg ikke selv kunne klare et så »lidet « indviklet forhold eller spørgsmål. I mit sidste seminarieår, da han skrev eller grundlagde sin danske grammatik, blev jeg og to andre elever hans $»$ forsøgskaniner - det mente vi da! - og hans undervisning $\mathrm{i}$ analyse og dansk grammatik har været mig en stor hjælp i min mangeårige lærervirksomhed, hvori dansk ikke blot var hovedfag, men så afgjort det allervigtigste. Byskov elskede den sokratiske metode, vendte spørgsmålet mod den spørgende og ydede under samtalen kun hjxlp til selvhjxlp, så at vi til sidst over for os selv måtte indrømme, at sagen eller opgaven var let og ligetil, blot vi benyttede vor omtanke.

Følgen heraf blev for mit vedkommende, at jeg som lærer allerede fra første færd søgte fejlen hos mig selv, når en elev kun mangelfuldt kunne folge undervisningen $i$ et af mine fag. På samme måde er det gået mig som fortæller, når jeg i mine timer ikke havde alle nogenlunde normalt begavede elevers opmærksomhed. Jeg måtte da tænke på P. Bojsen og min elskede lærer fra Vejle realskole; de havde altid kunnet erobre deres elevers øren, og mangelen på opmærksomhed affødte derfor $i$ de fleste tilfælde en anklage mod mig selv.

Det var en stor lykke, ja vistnok afgørende for mig som larer og dermed også i nogen måde afgørende for min fremtid, at jeg i min ungdom sad på skolebænken hos sådanne folk.

I 1894 bestod jeg 23 år gammel lærereksamen med 1ste karakter og fik straks plads som lærer på Uldum højskole. Men da skolen var på retur og ikke havde sommerskole for piger, søgte jeg om foråret plads på Ondløse højskole ved Holbxk, og den fik jeg; jeg skulle have $600 \mathrm{kr}$. årligt $\mathrm{i}$ løn samt værelse og kost - en ringe løn efter forholdene i dag! - men dengang regnedes den for god, og arbejdet 
tiltalte mig. Skolen var lille $-15-20$ elever - men netop af den grund blev en grundig og nøje tilknytning til hver enkelt elev en selvfølge, og dette blev mig en god hjælp til senere at kunne vurdere det standpunkt, hvorpå mine elever stod, både som mennesker og som elever på en skolebænk.

I Ondløse mødte jeg for første gang min vordende kone. Hun var det, man dengang kaldte "ung pige $\mathrm{i}$ huset «, og både hun og hendes hjem blev gode - ja, jeg kan godt sige uundværlige milepxle på min vej $i$ livet. I dette sogn - Starup-Nebel nord for Kolding - rejstes Danmarks første folkelige forsamlingshus, idet man her fra første færd var med i de folkelige, kirkelige, politiske og økonomiske bevægelser, der fra ca. 1850 var gået hen over vort land, der på egnen ved den kendte fynbo Peter Larsen Skræppenborg, som i 1841 købte en af sognets største gårde. Nu ringede begyndelsen til en ny tid ind for egnens folk ved talrige møder, han holdt om tidens nye krav til kirkens forkyndelse, skolens undervisning og rigsdagens politiske og sociale virksomhed - altsammen $\mathrm{i}$ Grundtvigs ånd og tankegang.

$\mathrm{Da}$ jeg i 1896 gennem min kones hjem stiftede bekendtskab med dette sogn, var det andet slægtleds virke, jeg mødte, og dermed $\mathrm{i}$ praksis meget af det, der i Skræppenborgs tid endnu kun var fremtid - f. eks. en grundtvigsk frimenighed med egen kirke, en grundtvigsk friskole samt en betydelig udvikling inden for andelsbevægelsen.

Min vordende svigerfar Jens Daugaard var levende med $\mathrm{i}$ alle disse bevægelser. Han havde været på Rødding og Askov højskoler og var formand i Ågård valgmenighed samt ejer af gården "Toftvang “ i Fredsted, der blev et velset samlingssted for det vågne StarupNebel sogn; thi svigermor Maren Daugaard, der var en datter af gårdejer Hans Ladegaard i Højrup, Skræppenborgs gode ven, kunne godt tåle at stå mål med sin mand, når det gjaldt omtanke, og hun var tillige skattet for sin store gxstfrihed. Kun fă steder gled en aften så hyggeligt som der.

Min nære tilknytning til dette hjem blev derfor en stor berigelse for mig og en god fortsættelse af, hvad der havde mødt mig på Gedved seminarium, men især står jeg dog i taknemlighed til min kone. Allerede fra forste færd evnede hun at holde hus på en kostskole, og hun blev en så uerstattelig medhjelper $i$ min virksomhed som grænseskoleforstander, at jeg $\mathrm{i}$ dag ikke er $\mathrm{i}$ tvivl om, at jeg $\mathrm{i}$ høj grad må dele xren med hende for, at det lykkedes for os at starte 


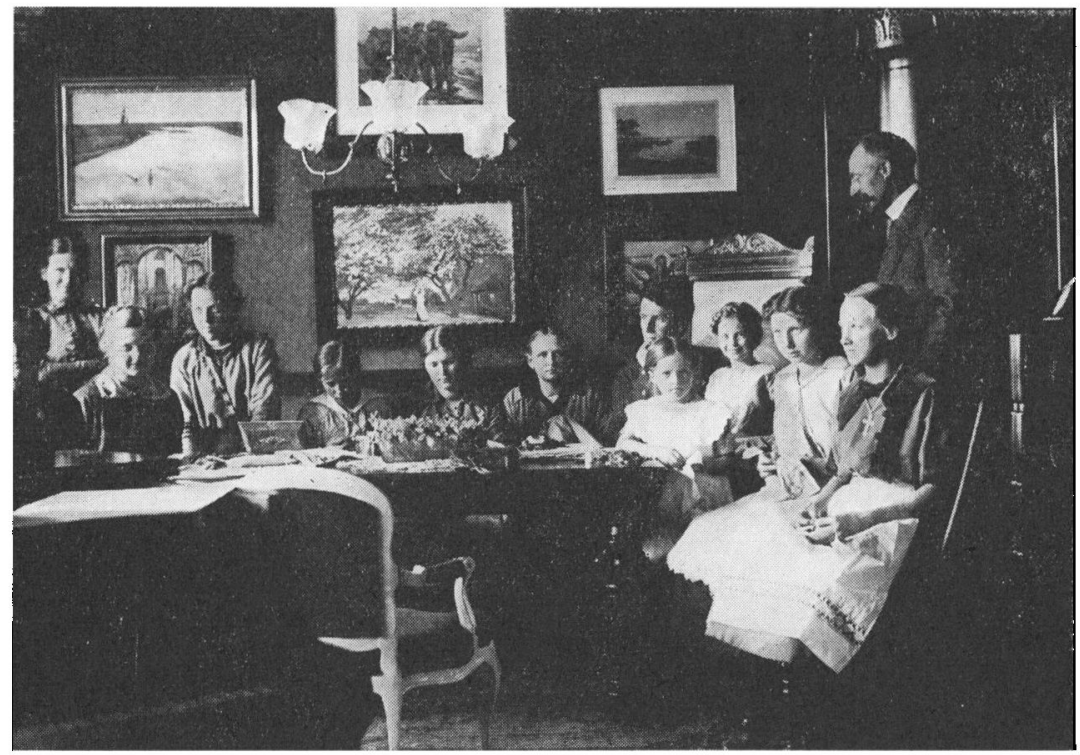

Sommerpiger $i$ dagligstuen på Hejls efterskole.

den nye Bramminge efterskole $i$ en vanskelig tid og senere gøre den mere end halvt tomme Hejls efterskole til den største af alle grænseskolerne. Til dette bidrog hun ved sin gode og naturlige forbindelse med eleverne og glæde ved at samle dem ved sit flygel $\mathrm{i}$ vor store private dagligstue om den rigdom af gode sange, Danmark ejer. Som eksempel på hendes forstående forhold til eleverne kan jeg anføre følgende: ved måltiderne havde hver elev sin bestemte plads, valgt af dem selv den første skoledag, og ved den lejlighed mødte der som regel så mange "vælgere« ved det spisebord, hvor min kone - uden tvang, men med god orden - førte an, at de umuligt alle kunne få plads der; de overskydende måtte så, en smule skuffede, nøjes med at få plads ved mit eller et af lærernes borde. Det var tidligere elevers omtale af min kone, der var skyld i dette kapløb af elever, der aldrig før havde set hende. - Blev eleverne syge, vidste de og deres forældre, at de kunne vente god pasning, og selv om eleverne var raske, vidste forældrene, at de altid var velkomne på skolen og kunne blive natten over.

Alt dette kunne naturligvis ikke ske uden tillæg af arbejde og offer 
af tid, og dog kan jeg ikke huske, at hun beklagede sig; thi hun forstod lige så godt som jeg den betydning, det havde, at så mange sønderjyder som muligt fik kendskab til det stykke Danmark, en grænseskole var; for vel var den dansksprogede forståelse god, men der var i de mange års tilhørsforhold til Tyskland ændret meget og sket så rig en udvikling heroppe, at hovedparten af befolkningen ganske naturligt måtte være fremmed for meget af det Danmark, der senere skulle møde den i 1920. - Inden jeg slutter min taknemlige omtale af min kone - Karen hedder hun og var født 1877 - må jeg for fuldstændigheds skyld tilføje, at også vore mange medhælpere gennem årene satte pris på hende.

Men jeg må i min fortælling tilbage til Ondløse højskole. Under min virksomhed der mødte jeg ikke blot min vordende kone, men havde også to andre oplevelser af betydning for min fremtid.

Takket være Ludvig Schrøder, Askov, og Alfred Poulsen, Ryslinge, søgte højskolens mænd $\mathrm{i}$ halvfemserne forbindelse med universitetets professorer ud fra det synspunkt, at videnskaben og højskolens folkelige arbejde burde finde hinanden $i$ deres fxlles trang til at gavne folk og land. Hidtil havde sympatien mellem højskolens og universitetets mænd ikke været stor, til tider endogså negativ, men vistnok takket være rigsarkivar A. D. Jørgensen tog universitetet mod højskolens udstrakte hånd.

I 1895 afholdtes så det første højskolelærerkursus ved universitetet i København i forbindelse med flittige og velledede besøg på museer og kunstsamlinger. Senere rykkede disse kursus hvertandet år ud på en af de større højskoler, hvor enkelte af højskolens mænd førte ordet sammen med et vist antal professorer. Da alle deltagere boede på vedkommende skole, sov i elevværelserne, spiste ved samme bord og således tilbragte dagen sammen, formede livet sig omtrent som $\mathrm{i}$ de bortdragne elevers tid, og derved var der for de medvirkende professorer lejlighed til ved selvoplevelse at komme kernen $\mathrm{i}$ højskolens arbejde på nærmere hold. Højskolens mænd var så optagne af den sag, at de mødte mandstærke lige fra Schrøder, Nørregaard o.s.v. til os helt unge højskolelærere, og forelæsningerne, museums- og teaterbesøgene og samværet med universitetets mænd gav ikke blot os unge, men også adskillige af de ældre deltagere et stærkt indtryk af den begrænsede viden, der prægede de fleste af os, 
og dette blev for mange af os en kraftig opfordring til ikke at nøjes med, hvad vi til dato havde fået gennem vor uddannelse.

Dette var den ene store oplevelse. Den anden, som også skyldtes dette kursus, oplevede jeg en måned senere.

Ved en af de store aftensammenkomster under kurset opfordrede højskoleforstander Salling, Ribe, de yngre højskolelærere til at gæste Sønderjylland $i$ deres ferier, og han ville så sørge for, at de, der meldte sig, fik lejlighed til at læse op eller holde foredrag ved sammenkomster i private hjem.

Sallings levende skildring af, hvorledes de danske sønderjyder med tyskuddannede præster, tyske børneskoler, tysk soldatertjeneste og de mange tyske forbud var henvist til at hjælpe sig selv, gjorde et stærkt indtryk på mig, og jeg meldte mig straks som deltager $\mathrm{i}$ dette arbejde. Kort efter meddelte Salling mig, at jeg skulle tale ved to sammenkomster, en i Kastrup og en i Gabøl, begge i nærheden af Gram.

I Kastrup havde jeg om eftermiddagen for mødet en oplevelse, jeg aldrig vil glemme. På vej til en nabo mødte min vært, den gamle Rasmus Hansen, og jeg en lille pige, som kom fra skole. "Nå, hvad har din tyske lærer så fortalt dig i dag, Marie? «, og den opvakte lille pige svarede med overbevisning i stemmen: "Æ trouer it et ord af, hva' han sejer $\%$.

Hvilket perspektiv åbnede dette barns udtalelse ikke med hensyn til forholdet mellem skole og hjem! Så ung hun end var, var hun allerede med $\mathrm{i}$ kampen for sin danske tilværelse, foreløbigt rettet mod den mand, der var hendes lærer, og for første gang så jeg helt klart den nød, som Sønderjyllands befolkning stod midt i. Den dag anede jeg endnu ikke, at jeg om få år skulle være med i den kamp og få et førstehånds kendskab til de tyske myndigheders hele færd for at drabe dansk sind og tankegang $i$ en gammel dansk befolkning.

$\mathrm{Da}$ Rasmus Hansen åbnede mødet med at byde mig velkommen som »en røst fra moderlandet «, og jeg samtidig følte, at forsamlingen var mødt med forventninger netop af den grund, følte jeg mig så lille, at jeg skammede mig over at have sagt ja til Sallings opfordring. Men da forsamlingen derefter sang: »I Danmark er jeg født, der har jeg hjemme ... * og gjorde det med en overbevisning og styrke, som ganske betog mig, forsvandt al min beklemthed, og stående ved kaffebordet $\mathrm{i}$ den tæt pakkede storstue holdt jeg så mit foredrag om Ingemann og hans historiske romaner - et foredrag, jeg også har 
holdt heroppe i det gamle land, men aldrig med den varme og styrke, som hin aften $i$ Kastrup - vel sagtens fordi det var så let at bringe denne forsamling i forbindelse med valdemarstidens trængsler og sejre. Jeg ser endnu den glans, der lyste mod mig fra adskillige øjne, da jeg sluttede med Ingemanns ord: "Hvad Danmark var, kan det atter blive, endnu er fædrenes ånd i live«. Efter foredraget blev vi sammen til midnat; den ene sang afløste den anden, og jeg følte mig hensat til en ukendt verden, en øde $ø$, hvis beboere med langsel stirrede mod den store lykke, det er at bo midt $i$ sit folk $i$ et frit land.

$\mathrm{Da}$ jeg den følgende aften talte hos gårdejer Laust Ankersen i Gabøl, var de tyske myndigheder allerede opmærksom på, at en kongerigsk højskolelærer »rejste rundt $«$ og holdt foredrag i private hjem, men de havde ikke kunnet opsporge, at gendarmerne netop den aften kunne træffe mig i Gabøl, og først da jeg var rejst tilbage over grænsen, indfandt de sig hos min vært, der til sidst dog slap med en bøde for at have huset en "udlænding « uden at anmelde dette.

Kampen for Sønderjylland havde allerede som dreng optaget mig, takket være de $x$ ldres fort $x$ lling om tysk indkvartering i min fødeby både $\mathrm{i}$ Treårskrigen og i 1864, og især var to daglejere hos min far en fra hver af disse tider - gode fortællere. Om ham fra Treårskrigen gxlder tillige, at han havde en god sangstemme og en god hukommelse, og vi fire brødre var som drenge gode tilhørere, når han sang soldatervise efter soldatervise fra den tid; navnlig var vi stærkt optagne, når han sang visen om Treårskrigens tapre generaler; hver af dem fik et vers, og hvert vers endte med omkvædet:

\author{
Han skal ha' et hurra, \\ der kan runge ned til Rendsborg, \\ så de kan huske på, \\ hvor de sidste gang ham så!
}

Hans sang gav de aftengilder en egen glans, der blev holdt i mit hjem for husets folk og arbejdere, når vi havde ophøstet, eller det sidste neg var kommet $\mathrm{i}$ hus, samt ved årets høstgilde, og denne glans har jeg i friskt minde endnu. Det var sejrene og de tapre generaler fra 1848-50, som min drengefantasi havde brug for, mens tilbagetoget fra Danevirke 1864 kun fik en beskeden plads.

Som voksen var det gået mig som så mange andre, der affandt sig 
med tabet af Sønderjylland som en kendsgerning, der ikke lod sig ændre med den ringe våbenmagt, Danmark havde; men de to aftener i Kastrup og Gabel stillede mig ansigt til ansigt med en anden magt, nemlig styrken i den danskhed, som sønderjyderne ejede; de turde håbe det tilsyneladende umulige - det turde de fleste heroppe i det gamle land ikke, og derfor var denne sag for os endt $i$ en slags samaritergerning til lindring af den værste åndelige nød i Sønderjylland.

Efter mit besøg i Sønderjylland levede jeg med i forholdene derovre, og H. P. Hanssen blev nu ved sit lyse syn og sin tilrettelæggelse af kampen på langt sigt min ungdoms helt. "Det har slet ingen hast for dem, som tror «, sang hans ven Johan Ottosen, og jeg blev trods det tilsyneladende umulige! - en af de troende, takket være H. P. Hanssen og den danskhed, jeg havde mødt i samfundet derovre.

Det var derfor ganske naturligt, at jeg uden betænkning sagde ja til at forlade hojskolen og gå aktivt ind $\mathrm{i}$ det nationale arbejde ved grænsen, da jeg i 1897 - det tredje år i Ondløse - ved seminariets anbefaling fik tilbud om at blive forstander for den femte og nye grænseskole, der var under bygning i stationsbyen Bramminge.

Langs grænsen lå der i forvejen fire grænseskoler, hvis elever næsten alle kom fra Sønderjylland, nemlig Hejls, Skibelund, Holsted og V. Vedsted efterskoler. Tilgangen var så stor på dette tidspunkt, at de alle var fyldte, og hertil kom, at der med god grund kunne ventes fremgang i elevtallet fra Sønderjylland.

Grænseskolerne, dog ikke V. Vedsted, var oprindelig grundtvigske friskoler, ganske svarende til de fynske friskoler, men efterhånden som de danske lærere frivilligt eller tvunget af myndighederne forlod Sønderjylland, sendte adskillige sønderjyske hjem deres ukonfirmerede børn til disse private børneskoler. Da denne bevægelse voksede, blev den imidlertid en faktor, tyskerne begyndte at regne for "farlig«, og en skønne dag udstedtes der forbud mod at sende skolepligtige børn på skoler i Danmark. Følgen heraf blev ganske naturligt den, at der ved de grundtvigske friskoler langs grænsen oprettedes en afdeling for konfirmerede børn fra Sønderjylland. Således opstod de såkaldte "grænseefterskoler*, og $\mathrm{i}$ Sønderjylland forstod man hurtigt den betydning, et sådant skoleophold havde — både for børnenes personlige udvikling og for den nationale kamp.

Min tilknytning til kampen i Sønderjylland var skyld i, at jeg som 
forstander i Bramminge holdt ud i den trange begyndelse, der straks i 1898 mødte mig på grund af Köller-politikken. Von Köller ramte hårdt $\mathrm{i}$ den nationale kamp, $\mathrm{da}$ han i praksis satte alle de sønderjyder på det sorte bræt, der sendte deres børn på danske højskoler og efterskoler; thi som følge heraf kom f. eks. de fire gamle grænseskoler til at stå halvt tomme, og den nye i Bramminge havde kun et par sønderjyske elever.

Det så trist ud for den nye skole og for os som nygifte, der drev skolen for egen regning og mod forventning måtte nøjes med en mindre flok fra egnen; det var jo ikke derfor, vi var kommet til Bramminge. Men håbet om bedre tider kunne jeg ikke opgive, og da jeg ejede noget af min fars uvilje mod at "give op«, ansporede dette mig til at se mig om efter noget, der kunne gøre det muligt at vente på bedre tider. Her var heldet igen med mig ved, at der meldte sig et sådant arbejde, idet en kreds af forældre onskede oprettet en privat børneskole, der gav udvidet undervisning, og om muligt en afdeling, der førte eleverne op til præliminæreksamen som privatister.

Jeg gik ind herpå og havde $\mathrm{i}$ de følgende fire år megen glæde af dette rent foreløbige arbejde.

Samtidig havde jeg den glæde at følge Gustav Johannsens, H. P. Hanssens og redaktør Jessens angreb på Köller-politikken og dens eftervirkninger, henholdsvis $\mathrm{i}$ den prøjsiske landdag og den tyske rigsdag, og ved disse mesterlige angreb se det sunkne mod rejse sig så vidt derhjemme i Nordslesvig, at mange sønderjyder blev klar over, at den eneste udvej til bevarelsen af danskheden var den at tage forholdene, som de lå, og i alle måder te sig som danske trods udvisninger, forfølgelser og straffe og til forsvar benytte de få tyske love, som von Köller ikke kunne tilsidesærte, og deriblandt landsdelens juridiske ret til opretholdelse af de tre store danske foreninger: Vælgerforeningen, Skoleforeningen og Sprogforeningen, som mange en overgang kun havde været medlemmer af $i$ stilhed.

Med denne beslutning gjaldt det især om at samle befolkningens aktivitet om disse tre foreninger, men jeg holder mig her til, hvad der skete inden for Skoleforeningen, thi $i$ dette fik jeg en lille andel, - uden at jeg i dag kan forstå, hvorledes dette kunne ske, lidet bevandret som jeg endnu var i sønderjyske forhold!

Jeg havde naturligvis som ny grænseskoleforstander prxsenteret mig for "Nordslesvigs Skoleforening «s bestyrelse, men hos kassere- 
Bramminge efterskolcs unge forstanderpur 1898.

ren, gårdejer Hinrich Thomsen, Roost, der tillige var foreningens sekretær og bestyrelsens mægtigste mand, fik jeg det afvisende svar: »Vi har for tiden ingen brug for Dem, Ravn, og heller ikke for Bramminge efterskole! « Hans kone udbrød da også: "Men Henrik da! « Hans svar opfattede jeg uheldigvis også som en mod mig rettet personlig afvisning, og skuffet forlod jeg hans hus og drog til Sundeved, som var den landsdel, jeg kendte bedst i Sønderjylland og anså for den landsdel, der havde tabt mindst af modet.

$\mathrm{Da}$ jeg året efter atter besøgte Sundeved, cyklede jeg på tilbagevejen gennem Roost uden at ane, at jeg ved den lejlighed skulle få en af mit livs mest uforglemmelige oplevelser.

Hinrich Thomsen gik just og puslede med et eller andet arbejde på vejen ind til sin gård, og som følge af min skuffelse året forud lod jeg, som om jeg ikke så ham, men han genkendte mig og bad mig standse; på vejen hen til ham mente jeg, at hans hensigt var at give mig en undskyldning, og min forbavselse blev derfor meget stor, da han meddelte mig, at han havde noget vigtigt at tale med mig om, og jeg synes endnu at kunne mærke den spxnding, jeg var $i$, mens vi vandrede ind $\mathrm{i}$ hans store gård. - Efter at have hentet et papir $\mathrm{i}$ sin skrivebordsskuffe fortalte han mig indledende, at Skoleforeningens bestyrelse havde holdt møde dagen før hos frimenighedspræst, pastor Poulsen i Bovlund for om muligt at få det mere end halvt standsede skolebesøg på danske efterskoler og højskoler i god gang igen, og at man hurtigt var blevet enige om, at vejen gik gennem Skoleforeningens tillidsmænd, hvoraf der var én i hvert sogn; deres opgave var at tegne medlemmer, opkræve medlemsbidrag og personligt besøge de hjem, hvor der var ungdom i passende alder til danske høj- og 
efterskoler; dette arbejde var mange steder gået helt i stå, og på én eller anden måde måtte tillidsmændene stilles over for den alvorlige kendsgerning, at danskhedens bevarelse i Nordslesvig var en opgave, som ikke kunne klares af hjemmene uden hjxlp af ungdommens besøg på danske skoler, og forhandlingerne endte med, at en skriftlig henvendelse til tillidsmændene skulle bæres ind ad døren til dem af en mand, der personligt egnede sig til at drøfte sagen med dem i alle enkeltheder; men hvor gik den mand? Bedst var det måske, sagde et medlem, at det blev en dansk skolemand, der i stilhed med personlig interesse for sagen ville vove sig ud på denne færd, med udsigt til udvisning og dermed afskærelse af al personlig forbindelse med Sønderjylland, om de tyske myndigheder fik øje på ham.

Denne plan vandt tilslutning, og så vidt jeg véd, var det pastor Poulsen, som kendte lidt til mig, der foreslog, at man henvendte sig til den nye grænseskoleforstander i Bramminge, og dette blev sammen med den skriftlige henvendelse fra bestyrelsen resultatet af mødet.

Den sag var det, Hinrich Thomsen skulle ordne med mig og, hvis jeg sagde ja, da instruere mig nærmere og anvise mig de sogne, hvori jeg skulle gøre et første forsøg.

Det var mig en glxde at sige ja - også af den grund, at det for mig ville være en god lejlighed til at lære sønderjyske forhold bedre at kende, end jeg gjorde, og instruksen lød: »Her har du en liste over alle Skoleforeningens tillidsmænd på vestkysten; du begynder hos købmand Filskov i Møgeltønder, han er retvendt og klog, og derfra går du videre til sognene nord for Møgeltønder; men vær forsigtig! bo privat og bed din vært om ikke at melde dig som liggende gæst, og se overalt sammen med tillidsmanden at besøge så mange solide danske hjem som muligt, hvor der er ungdom i højskole- og efterskolealderen!«

Instruksen var god, og jeg gennemtrawlede alle vestjyske sogne lige til den danske græense og mindes endnu, hvor glad Skoleforeningens formand, gårdejer Thyssen Hansen i Randerup, blev, da jeg kunne fortælle ham, at turen var lykkedes så godt, at tilgangen til danske høj- og efterskoler antageligt ville vokse betydeligt på vestkysten i det kommende efterår, og således gik det da også.

Neste år sendte Hinrich Thomsen mig til Sydals, og her gik det lige så godt, takket være den nationalt stærkt virkende gårdejer Peter Kaad i Vollerup, der ofrede flere dage på at følge mig rundt 


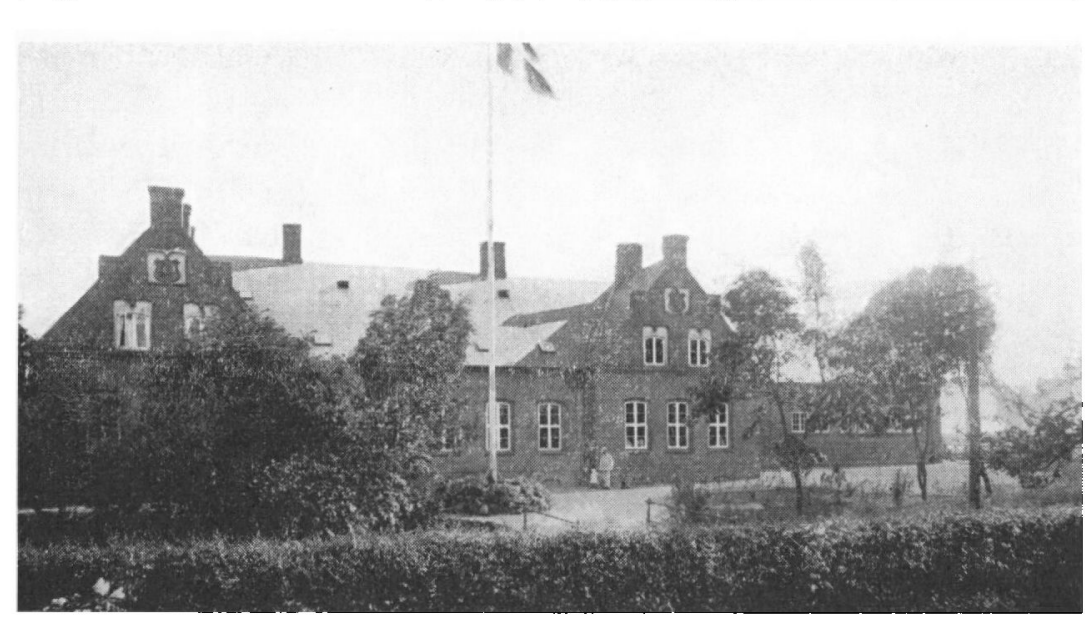

Hejls efterskole, hovedbygningen.

til tillidsmændene, men dermed var det også forbi med så omfattende besøg, thi på en eller anden måde havde myndighederne fået noget at vide om min færd, men da var jeg borte, og hvem jeg var, fik de aldrig fat på. I de følgende år gjaldt mine besøg især tillidsmændene, da systematiske besøg i hjemmene sammen med disse var farlige og heller ikke så nødvendige med befolkningens voksende mod, der bl. a. viste sig $i$, at en større strøm end nogen sinde før af sønderjysk ungdom søgte over på danske skoler.

Den nye grænseskole fik derved fuldt hus af elever, og allerede i 1903 vovede vi at opgive såvel den private børneskole som præliminærafdelingen, og kort efter tilbød de 70 samvirkende sønderjyske foreninger i Danmark min kone og mig forstanderpladsen ved deres store smukke grænseskole i Hejls, som det trods sønderjysk interesse og penge ikke var lykkedes dem at få i god gang, bl. a. på grund af den begrænsede magt, forstanderen måtte nøjes med, med hensyn til antagelse og afskedigelse af medhjælpere. Da disse forhold var velkendte, svarede jeg straks trods den gode løn, man bød os, at vi ikke kunne tænke os at forlade Bramminge efterskole, med mindre vi i Hejls fik bygningerne overladt til fri brug for egen regning som grænseskole og selv antog, lønnede og afskedigede vore medhjælpere uden indblanding fra foreningernes side; dette var mere, end man straks kunne gå med til ud fra den betragtning, at skolen jo så blev 
min skole og ikke foreningernes. Men den kloge pastor Hansen $\mathrm{i}$ Ribe, der var formand i skoleudvalget, søgte at vise hovedbestyrelsen, at dette ikke var tilfældet, da det fremdeles var foreningernes ret at afskedige og antage skolens forstander, og at det var hovedsagen, at den kom godt i gang, og resultatet blev, at man i 1904 kom igen og bad mig affatte et udkast til en mulig kontrakt, og skønt den ganske svarede til, hvad jeg forlangte året før, blev der flertal for den $\mathrm{i}$ hovedbestyrelsen, og $\mathrm{i}$ april holdt vi så vort indtog $\mathrm{i}$ Hejls.

Som den største af grænseskolerne $\mathrm{i}$ bygning kunne den tage mod 50 elever, men så højt nåede vi ikke straks, da den vinteren forud kun havde haft 14 elever, men vi kunne dog den 3. maj åbne sommerskolen for piger med 35, og allerede den første vinter havde vi fuldt hus af 15-17-årige drenge, og både sommer og vinter fik vi i de følgende år flere indmeldelser, end vi kunne tage imod.

$\mathrm{Da}$ bygningerne således blev taget $\mathrm{i}$ fuldt brug, forsvandt den sidste rest af misfornøjelse med den magt, min kontrakt gav mig, og foreningerne var efter fire års forløb endogså villige til at udvide bygningerne, så skolen kunne rumme 80 elever. Hertil bidrog for det forste de mange indmeldelser og for det andet ønsket om udvidelse af gymnastiksalen, så der blev bedre plads til det stigende besøg sydfra til de fire årlige møder, som foreningerne afholdt på skolen. Endvidere var jeg meget interesseret $i$, at skolen fik mere gæsteværelsesplads på grund af dens nære beliggende ved Skamlingsbanken, over hvilken vejen gik for mange danske på deres sommertur til Sønderjylland. Som de 70 foreningers ejendom havde Hejls efterskole også et navn i Danmark. Det var desuden ret kendt, at min kone og jeg var gæstfrie og ikke blot gerne ville hjælpe de rejsende med at lægge en plan for deres Sønderjyllands-rejse, men også i sagens interesse give dem lejlighed til at færdes mellem 80 sønderjyske piger i sommerskoletiden og se og høre, hvorledes vi arbejdede med dem. Dette havde til følge, at de rejsende ved deres besøg $i$ en landsby som Hejls of te kom til at mangle natlogi. Havde vi lidt mere plads, kunne vi for det første hjælpe flere i Danmark til at få et indblik i det nødvendige arbejde, der foregik på en grænseskole, og for det andet kunne jeg - ved planlæggelsen af rejsen - med mit kendskab til hjem i de fleste sogne derovre hjælpe de rejsende inden for døren i sønderjyske hjem og samtidig sørge for, at også de egne, som kun fik få eller ingen besøg fra Danmark, kom i betragtning, - til 


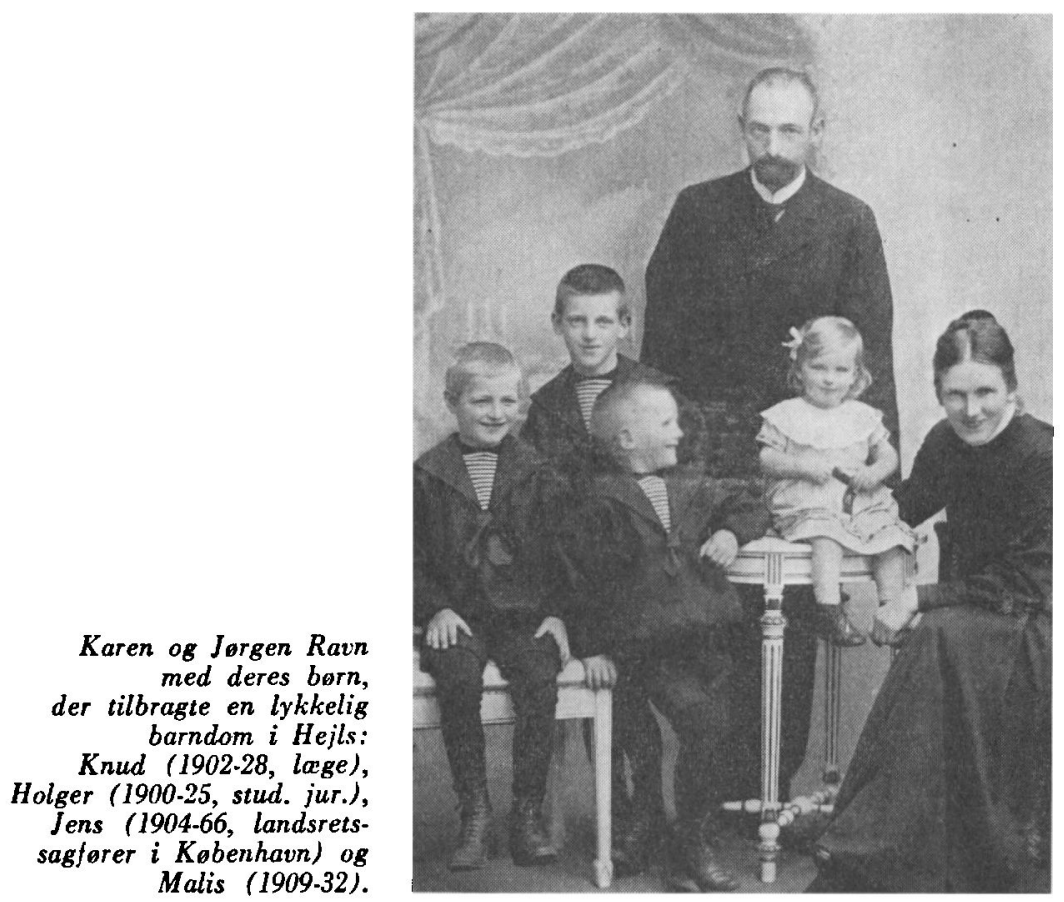

gavn for begge parter, når de rejsende forud var sat lidt ind i $f$. eks. forskellen på Sundeved og egnen Tinglev-Tønder med hensyn til kendskabet til Danmark eller forskellen på Als og Vestslesvig i deres sympati, når det gjaldt $\mathrm{H}$. $\mathrm{P}$. Hanssen eller Jessen - de to store førere.

Kort sagt: Skolen manglede plads for at kunne tage mod flere elever og mere gæsteværelsesplads samt et lille sygehus, og alle tre dele var foreningerne villige til at skaffe os sammen med en forstørrelse af gymnastiksalen, så den kunne rumme 500 tilhørere, af hvilke flertallet kom fra den anden side af grænsen.

I 1909 stod udvidelsen færdig, og nu havde vi plads til de 80 elever, vi straks fik, samt til de store møder, og vore gæsteværelser var of te fuldt belagte om sommeren.

Hermed fulgte naturligvis en betydelig forogelse af både min kones og mit arbejde, men for os begge fulgte ganske af sig selv, at vi betragtede de rejsende fra kongeriget og elevforældre som vore 
gxester; derimod betalte foreningerne foredragsholderne og det store fælles kaffebord, som min kone ordnede ved møderne.

Som en fuldstændig tilintetgørelse af dette travle arbejde kom så i 1914 den første verdenskrig, for med den standsede så at sige tilgangen til grænseskolerne. Lovlydige, som de fleste sønderjyder var af hensyn til fremdeles at kunne klare den nationale kamp i fremtiden, drog de gamle elever i krig, og den ungdom, som ellers ville have fyldt grænseskolerne, beholdt forældrene af den samme grund hjemme under krigen. Det ville derfor have set sort ud for os okonomisk, der ifølge vor kontrakt drev skolen for egen regning, om foreningerne ikke efter nogen tids forløb - uventet! - havde sendt os $300 \mathrm{kr}$. i hver måned, så længe krigen varede, og dem tog vi imod med glæde, ikke som en almisse, men som en tak for det ubetalte arbejde, vi havde udført igennem årene ud over selve skolearbejdet.

Da krigen i 1918 hørte op, og det gik mod Nordslesvigs genforening med Danmark, besluttede foreningerne at flytte deres skole til Kruså, og skoleudvalget opfordrede min kone og mig til at følge med. Men da man inden for foreningerne ret ofte mødte den anskuelse, at nu var man færdig med Nordslesvig, og at det nu var Sydslesvig, det gjaldt, fandt jeg det nødvendigt, at min kontrakt fik en tilføjelse om, at jeg ikke var pligtig til at tage mod mere end 33 pct. af elevantallet fra Sydslesvig, hvor børnene jo fremdeles ville komme til at gå $\mathrm{i}$ tysk skole og komme fra mindre udpregede danske hjem end den gamle elevflok i Hejls, der næsten udelukkende var fra Nordslesvig. Ifølge mine erfaringer herfra gik det ikke an hvis det blev muligt! - at fylde den nye skole med sydslesvigske elever, - ikke så meget af hensyn til den tyske skolegang, disse børn fremdeles ville få, som af hensyn til, at de foreløbigt ville komme fra hjem, der levede et liv fjernt fra næsten al forbindelse med dansk tankegang; skulle skolens lærerkræfter være eneste danske faktor, ville der efter min mening komme alt for lidt ud af arbejdet, men var ca. 66 pct. af eleverne nordslesvigere, ville deres kammeratskab være en hjælp, som i praksis ville vise sig at være uundværlig for skolen. Men foruden dette hensyn var der et hensyn at tage til Nordslesvig, der trods den kommende danske børneskole ikke godt kunne undvære de gamle grænseskolers arbejde foreløbigt, - i alt fald ikke de første 10 år. 
Begge forhold drøftede jeg grundigt med skoleudvalgets formand, provst Hansen, nu Helsingør, der nøje kendte forholdene både $\mathrm{i}$ Syd- og Nordslesvig fra sin præstetid i Ribe, og da han herudfra fandt den ønskede kontrakttilføjelse både rimelig og rigtig og var nogenlunde sikker på, at den kunne vedtages $\mathrm{i}$ bestyrelsen, slog jeg mig til tåls hermed.

Under krigen havde foreningernes officielle arbejde måttet ligge stille, og man ventede med længsel efter at tage det op igen, men da ordningen af forholdene vedrørende det sammenbrudte Tyskland tog sejrherrerne hele to år, gik der også så lang tid, før Danmarks nye grænse kunne drages, og da vi selv kunne få lov til at bestemme, hvor denne grænse skulle gå, blev der også god tid til, at stridens bølger kunne gå højt inden for foreningerne herom.

Den sønderjyske landsdel var jo lige til Ejderen gammelt dansk land, og de varmeste gemytter mente - efter Englands tilbud, der gav os frie hænder - at nu var tiden inde til, at vi af det tyske rov i 1864 kunne få tilbage, hvad der med rette var vort. Nogle gik så vidt, at de aldeles så bort fra et andet syn, der også måtte tages $\mathrm{i}$ betragtning, nemlig at Sydslesvig $i$ hertugtiden og især efter 1864 havde levet sig bort fra forbindelsen med moderlandet. Denne kendsgerning måtte der også regnes med, og det store spørgsmål var altså, hvor langt i syd den nye grænse kunne sættes.

Også inden for foreningerne havde der som sagt været delte meninger om, hvor grænsen burde gå, og muligt kunne dette få nogen indflydelse på de beslutninger, der ville blive taget på det første delegeretmøde, der denne gang kunne holdes i Sønderborg - på sønderjysk grund! - især da forsamlingen ville blive stor, idet hver af de 70 foreninger kunne sende fem delegerede.

En mindre kreds af forsamlingen, de såkaldte »ejderdanske«, gjorde hurtigt indtryk af at være energisk bitre over den grænse, vi havde fået, og antageligt var et betydeligt flertal af de ovrige deltagere som "flensborgfolk « også mindre fornøjet med grænsen, mens kun et større mindretal syntes tilfreds, og dette kunne da ved de beslutninger, der blev taget angående fremtidens arbejde og måske også ved valget af den nye bestyrelses sammensætning, medføre, at min fordring om den nævnte tilføjelse til min kontrakt kom i fare.

Ved de mange spørgsmål, der forhandledes, fremsattes da også et par gange den tanke, at foreningerne nu måtte være færdige med 
Nordslesvig, men så vidt syntes flertallet af forsamlingen dog ikke at ville gå. Ved bestyrelsesvalget valgtes et flertal af den gamle veltjente bestyrelses medlemmer, og derved syntes min kontrakttilføjelse sikret. Således kom det dog ikke til at gå, thi ved mødets slutning stod P. Grau, Pøl, på talerstolen og bad om tilladelse til at fremsxtte endnu et forslag, og med al den veltalenhed, han nu engang havde fàet $i$ vuggegave, foreslog han, at der af hensyn til arbejdet i Sydslesvig skulle nedsættes et orienteringsudvalg ved siden af den nyvalgte bestyrelse. Da forslaget i P. Graus mund lød meget uskyldigt, vedtoges det omgående uden drøftelse ved, at størsteparten af forsamlingen rakte hånden $\mathrm{i}$ vejret og dermed også godkendte hans forslag af navne hertil på folk, hvoraf de fleste var færdige med Nordslesvig og ikke forstod, at hvis Danmark atter skulle vinde frem i Sydslesvig, var et voksende samkvem mellem den opvoksende ungdom nord og syd for den nye grænse den bedste hjxlp, Danmark havde til rådighed - og dog måtte jeg vente at have dette udvalg til bitter modstander, hvis elevantallet sydfra oversteg de nævnte 33 pct.

Her må jeg indskyde en bemærkning - den nemlig, at arkitekt Strøm-Tejsen, København, på opfordring havde tegnet en ny skole, der skulle afløse Hejls efterskole og ligge ved Kruså; stor og pragtfuld var den, men da jeg efter det meningsløse valg af et orienteringsudvalg ved siden af den valgte bestyrelse nu ikke, som lovet, onskede at underskrive kontrakten som denne skoles forstander, sammenkaldte jeg straks skoleudvalget til et møde $\mathrm{i}$ hotellets have for at meddele dette min beslutning, og jeg kan endnu høre provst Hansen, der var udvalgets formand, udbryde: "Så slår De os i øjeblikkets vanskeligheder det bedste middel af hånden til at hindre, at oppositionen făr magten! « - Bag denne udtalelse lå der ikke så lidt af en bebrejdelse, og inderst inde måtte jeg jo indrømme, at jeg stod i stor taknemmelighedsgæld til udvalget, og dette fik mig til at vakle, men under min betænkning mærkede jeg bagfra et ryk i min trøje, og jeg hørte en mand hviske til mig: „Gør det aldrig, Ravn, kom ud til os i Tønder! - Der var altså en af mine gode bekendte og tillige en klog mand, der så på denne sag som jeg, og dette var nok til, at jeg ikke mere vaklede $i$ mit svar og benyttede lejligheden til at bringe udvalget en hjertelig tak for vort gode samarbejde i 16 år i Hejls.

Provst Hansen gav dog ikke op og inviterede udvalgets medlem- 
mer og mig til middag på et andet hotel end det, hvor mødedeltagernes fællesspisning fandt sted, og her forhandlede vi så videre, indtil provsten efter et par timers forløb sluttede samværet med onsket om, at jeg måtte finde en anden og god virkeplads i Sønderjylland.

Næste dag gik jeg op til Sønderborg amts skolekonsulent, hos hvem jeg fik en god modtagelse, efter at jeg havde fortalt ham lidt om mit arbejde ved grænsen gennem 22 år. - "De kommer", sagde han, nsom om forsynet havde udset Dem til overlærer i Nordborg! Ganske vist har vi en dygtig og tiltalende ansøger, der gerne vil have dette embede, men han er desværre ganske ukendt med sønderjyske forhold, og vi er i skoledirektionen betænkelige ved at anbefale ham, for Nordborg vil antagelig få en tysk afdeling på 60-70 børn, og der er den forhen så mægtige tyske amtsforstander og den tyske højskoleforstander på slottet valgt ind i skolekommissionen, og de fem danske medlemmer kan let få brug for en overlærer, der er velkendt med Sønderjyllands befolkning og skoleforholdene i den tyske tid. Den side af sagen regner jeg med er $\mathrm{i}$ orden hos Dem, men kan De lede et købstadsordnet skolevæsen med mellemskole og realklasse? *

*Antageligt kan jeg ret hurtigt erhverve, hvad jeg mangler i så henseende«, svarede jeg, "da jeg ikke blot er gammel skoleleder, men også nogle år på Bramminge efterskole tillige har været leder af en børneskole, der gav udvidet undervisning og sendte en del af eleverne op til præliminæreksamen som privatister. Desuden har to af mine sønner gået $\mathrm{i}$ mellemskole $\mathrm{i}$ Kolding, så jeg altså har et andenhånds kendskab til mellemskolen «.

»Rejs straks til Nordborg ", sagde han, wog held og lykke til at vinde de fem danske medlemmer, så De kommer med på indstillingen til embedet!*

I Nordborg blev jeg modtaget af formanden, gårdejer Jens Nissen, som om jeg var en af deres egne, og efter at jeg havde besøgt de øvrige fire danske medlemmer af skolekommissionen, bad man mig komme til Nordborg og hjælpe dem med at lægge en plan for det omfattende skolevæsen: en dansk og en tysk folkeskoleafdeling samt en eksamensafdeling med fire mellemskoleklasser og en realklasse.

Under alt dette sad min kone i Hejls og var ganske uvidende om, at der var ved at ske en forandring $i$ vor tilværelse, men som for- 
holdene lå, måtte der handles omgående med hensyn til vort ja eller nej angående Nordborg; på hjemvejen var jeg atter hos amtsskolekonsulenten og fik ved den lejlighed en kort betænkningstid.

På hjemvejen måtte jeg kæmpe med en følelse af, at jeg havde vendt ryg til et arbejde, der dagligt gennem 22 år havde været både min kone og mig en glxde at gå op i, og jeg var ikke uden frygt for, at min kone ville finde, at jeg havde forhastet mig med mit nej til at underskrive kontrakten, fordi der som opposition var blevet sat et orienteringsudvalg ved siden af den lovligt valgte bestyrelse en vanskelighed, som det ikke var let for udenforstående at komme til bunds i.

Forstander Appel, Askov højskole, måtte på én eller anden måde som undervisningsminister have fået at vide, at min kone og jeg var ledige, thi tre dage efter min hjemkomst fra Sønderborg satte han mig stævne i Tønder for at tilbyde mig pladsen som forstander for en efterskole, som han ønskede oprettet dér sammen med en skoleafdeling, der forberedte elever til optagelse på Tønder seminarium. Skolen skulle bygges på seminariets mark og indrettes således, at den egnede sig til afholdelse af større møder i lighed med grænsemøderne på Hejls efterskole.

Lidt uden for byen lå en tysk landbrugsskole, som stod tom, og den håbede han, at man kunne få til leje eller køb og benytte, indtil den nye skole var færdig; men her regnede ministeren fejl, thi tyskerne på egnen og i den del af Tønder amt, der blev ved Sydslesvig, ville hverken udleje eller sxlge skolen, da de opdagede, hvem køberen var.

Ved en ny forhandling foreslog Appel så, at jeg gik ind som lærer ved seminariets øvelsesskole, indtil den nye skole stod fxrdig på seminariets mark; men den løsning ønskede jeg ikke at gå med til, bl. a. også af den grund, at som forholdene lå, var et hurtigt regeringsskifte langt fra umuligt, og i så tilfælde var det jo ikke givet, at den nye undervisningsminister havde samme store interesse for den sag som Appel. - Kort sagt, jeg foretrak Nordborg, og dette har jeg aldrig fortrudt.

Det var nu på høje tid, at skolekommissionen overvejede enkelthederne $i$ et udkast til en skoleplan, og jeg tog derfor som lovet til Nordborg, hvor jeg fik mit daglige tilhold hos skolekommissionens formand og hans gæstfrie kone. Vi blev hurtigt enige om, 
at der var to hovedspørgsmål, som allerførst måtte klares: For det første: Var børneantallet stort nok til inden for et købstadsordnet skolevæsen også at kunne bære en eksamensafdeling med fire mellemskoleklasser og en realklasse? - og for det andet: Ville en så stor og uvant udgift til skolevæsenet ikke medføre utilfredshed hos en stor del af skatteyderne til skade for det gode forhold til skolen?

I øjeblikket var børneantallet så stort, at det kunne forsvares at oprette en eksamensafdeling, men på grund af krigen ville antallet af børn i nogle år synke år efter år, og nogle af klasserne ville da blive små med ca. 20 børn i de mindste. - Man ville dog nødigt opgive eksamensafdelingen, og jeg rådede derfor skolekommissionen til at bede borgmesteren indbyde skatteyderne til et mode. Dette møde gav fuldt hus, men desværre ikke nogen udtalelse om sagen, hverken fra borgmesteren eller forsamlingen.

Skolekommissionens formand indledede, og da ingen i den store forsamling bad om ordet, opfordrede han mig til at udtale mig om sagen, og jeg husker endnu omtrent ordret, hvad jeg sagde:

"Jeg har let ved at forstå, at man her på det tæet befolkede Nordals med så lang vej til Sønderborg skolevæsen ønsker en eksamensafdeling ved Nordborg skole, men De gør klogt $\mathrm{i}$ forud at holde den tanke fast, at udgiften til skolen vil stige betydeligt med fire mellemskoleklasser og en realklasse. Hvor meget den vil stige, vil bero på, i hvor høj grad oplandet vil udnytte mellemskolen, der kan give deres børn et godt grundlag til senere at få fuldt udbytte af opholdet på en landbrugsskole, en købmandsskole eller en håndværkerskole, og hertil kommer endvidere, at mellemskoleeksamen giver adgang til gymnasiet.

Jeg har som sagt derfor let ved at forstå, at man har lagt sig fast på ønsket om at få en udvidet undervisning, som den mellemskolen giver, thi for det første kan alle jævnt begavede børn, der er $\mathrm{i}$ besiddelse af nogen flid, følge undervisningen og drage nytte af den, ligegyldigt hvad de vil være, og for det andet kræver den kun et års skolegang ud over den almindelige skoletid.

Selve ordningen er altså god, og i dag er børneantallet i Nordborg så stort, at tilgangen til mellemskolen antageligt vil give ret store klasser, men på grund af den lige overståede krig har barnefødslerne været i nedgang fra 1914, og dette vil jo sige, at de skolesøgende børns antal vil blive mindre fra år til år i nogle år. Kan man imid- 
lertid regne med god tilgang til eksamensskolen fra oplandet, kan dette måske bøde på nedgangen både med hensyn til nedgangen $\mathrm{i}$ skoleudgiften og antallet af elever i mellemskoleklasserne.

Der er altså to ting, som De må se at blive klar over med hensyn til den fremtidige skoleordning: For det første: Kan De som skatteydere finde Dem $i$ at betale mere $i$ skat uden at blive utilfreds med den ønskede skoleordning, og for det andet: Kan De, som i den tyske tid var vant til at se 50-60 børn $i$ en klasse, tåle at se enkelte af klasserne synke ned til ca. 20 børn? «, og jeg sluttede med at sige: *Kan De tage denne overgang med det synkende børneantal uden at blive utilfredse med den onskede skoleordning, så er der god grund til her på det afsidesliggende Nordals at have en skole, der tillige har en eksamensafdeling! «

Nede i den store forsamling rejste en beruset mand sig og udbrød: *Børn, de kommer sgu' af sig selv!

Der var mange, der lo, men hans ord var de eneste, der blev sagt af forsamlingen angående selve sagen - ikke engang borgmesteren havde et vejledende ord at sige; - og så mærkeligt det lyder, arbejdedes der trods min fremstilling af sagen videre med skoleplanen uden opposition.

I mindet om amtsskolekonsulent Nielsen, Sønderborg, føler jeg trang til at bemærke, at når han så stærkt som omtalt ønskede at give Nordborg en danskuddannet overlærer, der på forhånd havde noget kendskab til sønderjyske forhold, så skyldtes dette ikke blot, at den forhenværende tyske amtsforstander - i sin tid en såre mægtig mand! - og den tyske højskoleforstander på Nordborg slot sad i skolekommissionen, men også den omstændighed, at han i de få måneder, han havde arbejdet i Sønderborg amt, havde opdaget, at noget af den berettigede og gennem årene voksende modstand mod det tyske herredømme havde skabt en selvstændighed i befolkningen, der antageligt også nu og da kunne melde sig over for dansk styre og dansk tankegang, f. eks. bestemmelsen om, at man i Danmark kun havde 36 børn, mens tyskerne havde haft 50-60 børn i klassen, eller om den *milde« behandling, Danmark ønskede at give det tyske mindretal i Nordslesvig. Derved var han kommet til det resultat, at de nyansatte danske embedsmænd foreløbigt - og deri var jeg enig med ham! - måtte fare med lempe, og at det derfor var nødvendigt at finde embedsmænd, der havde noget forhåndskendskab til sønder- 
jyske forhold og ejede god vilje til at forstå befolkningen - især hvor forholdene var særlig vanskelige. Mit kendskab til sønderjyske forhold kom mig hurtigt til gode - endogså før jeg var ansat i embedet.

$\mathrm{Da}$ skatteborgermødet trods mine fremsatte betænkeligheder ikke syntes at have gjort noget indtryk på forsamlingen med hensyn til den udgift, der ville følge med den købstadordnede skoleplan, arbejdede de fem danske medlemmer og jeg videre med den samt med en indgående overvejelse med hensyn til lærerkræfterne ved den tyske afdeling, som vi nu vidste ville komme til at tælle $69 \mathrm{børn}$; thi jeg anså det for vigtigt, at man fra dansk side kunne møde fuldstændigt enige ved det første fxllesmøde med de to tyske medlemmer.

$\mathrm{Da}$ vi var færdige, erklærede jeg, at jeg også ville aflægge et besøg hos de to tyske medlemmer; jeg var meget spæendt på, hvorledes dette besøg ville falde ud, for jeg vidste, at de begge var intelligente og krigsvante nok til at skabe uro ved skolen, - isxr da de uventet kunne møde med 69 børn og ifølge mit ophold i Nordborg nxppe kunne være uvidende om, hvem jeg var - nemlig en gammel modstander fra min tidligere stilling som forstander for en af de af tyskerne så forhadte grænseskoler; kort sagt en mand, der ville "krig" og bedst kunne holdes nede ved modkrig i stort og småt.

Jeg gik først til den før så mægtige amtsforstander Klincker, der havde været tyskernes højre hånd $\mathrm{i}$ administrationen af det gamle danske Nørherred og af befolkningen derfor ofte blev kaldt werredsfogden «, et navn, som han efter sigende slet ikke var ked af.

$\mathrm{Da}$ jeg præsenterede mig som forstander for Hejls efterskole og ansøger til overlærerembedet, gik der en trækning over hans ansigt, som om han ville sige: "Og dette byder man os sammen med lovens så kønne ord om behandlingen af de tyske afdelinger ved de danske kommuneskoler!«

"Bitte setzen Sie sich!« sagde han og pegede på en stol; selv blev han gående på gulvet, - bevæget og dybt nedtrykt af omvæltningen og Tysklands nederlag.

$\mathrm{Da}$ han havde vundet herredømme over sin bevægelse, udbrød han bittert og pă tysk: "Hvilke kår får vi nu ikke!«

»Dem tror jeg ikke, amtsforstanderen vil få gyldig grund til at beklage sig over! « svarede jeg.

»Hvor véd De det fra!« sagde han afvisende. 
„Det siger loven, det siger kongen, og det siger dansk tankegang!« svarede jeg.

" Ja, men administrationen!« sagde han spørgende.

«Den tror jeg heller ikke, at amtsforstanderen skal få grund til at beklage sig over, for det er ikke i Danmark som i Tyskland, at administrationen i politiske spørgsmål kan tilsidesætte dommer og lov! «

Denne udtalelse harmede ham så stærkt, at den kunne friste ham til at vise mig døren, og derfor skyndte jeg mig at tilføje: $\gg$ Må jeg ikke minde amtsforstanderen om Finnemann-sagen; den tyske domstol erklærede, at han var "prøjsisk borger" - ikke optant - men administrationen nxgtede dette og handlede derefter!

$\mathrm{Da}$ så han undersøgende på mig og sagde: "Ja, dengang gik bølgerne jo så utilladeligt højt«, og med den indrømmelse talte han for forste gang dansk til mig, og da jeg gik, sagde han: $»$ Tak for besøget!«

$\mathrm{Da}$ jeg senere - efter indstillingen - fortalte Jens Nissen den »historie", sagde han: "Ja, det ligner Klincker; han har ikke altid kunnet stå for folk, der selv havde en mening og evnede at forsvare den, og du har derved kunnet give ham indtryk af, at du er en frisindet mand, thi også dette forstår han at bruge $i$ sin interesse; derfor kan jeg nu forstå, at du kunne blive indstillet med alle syv medlemmers stemme som nummer et til overlærerembedet «.

Hos den tyske højskoleforstander, Christensen, var det nemlig gået mig lige så godt som hos amtsforstanderen, for da han $\mathrm{i}$ samtalens lob hørte, at jeg havde været højskolelærer $i$ fire år, kunne han ikke skjule sin beundring for den danske højskoles mål og arbejdsmåde.

Allerede ved det første fællesmøde optrådte de to tyske medlemmer yderst neutralt, - uden at dette gjorde noget indtryk på de fem danske, men heldigvis holdt dette sig i de to år, den tyske afdeling bestod ved kommuneskolen; ja, amtsforstanderens sympati for mig var endogså så stor, at han efter at have forladt Nordborg aflagde et privat beseg hos os. Da der var gået et års tid, flyttede han til Flensborg, men ved et besøg i Nordborg gik han ikke min der forbi; derved fik han en livlig samtale med min kone, der tillod sig at mene, at det efter en stor krig måtte være vanskeligt for Tyskland at betale sejrherrerne en så stor krigsgxld; men da rettede han 
sig på stolen og lod en hånd falde ned på bordet, idet han sagde: *Vi kan betale, og vi vil betale!«. Min kone, der ikke før havde mødt ham, fik uvilkårligt et stærkt indtryk af, hvor meget det var ham om at gøre at værne den tyske ære.

På begge sider af Storegade lå to forladte skolebygninger, den ene antagelig fra Frederik den Sjettes tid og narmest en ruin -, den anden, bygget af tyskerne efter $1864 \mathrm{og}$ endnu en god bygning med tre lærerlejligheder og to ubrugte klasseværelser; bag den havde eleverne en god legeplads, og længere tilbage lå en ny skolebygning med klasseværelser så store, at de kunne rumme 50-60 børn.

De to ubrugte klasseværelser havde altså direkte udgang til skolepladsen, og de fem danske medlemmer med deres afsmag for alt, der smagte af Tyskland, fandt det rigtigt at give den tyske afdeling denne selvstændige plads; dette var jeg langtfra enige med dem i, men tav $\mathrm{i}$ betragtning af, at dette faldt ind under overlærerens administration.

På åbningsdagen mødte skolekommissionen og nogle få forældre, og da klasserne marcherede ind, og den tyske afdeling vandrede mod hoveddøren i den nye skolebygning, kom Jens Nissen hen til mig, og han var vred! »Du hørte jo da $\mathrm{i}$ aftes, at vi bestemte, at vi ønskede den tyske afdeling anbragt $i$ de to gamle klasseværelser, og efter at tyskerne har mishandlet vore børn gennem $56 \stackrel{\mathrm{a}}{\mathrm{r}}$, sender du to danske klasser derover, hvor der aldrig kommer sol! — - Ja«, svarede jeg, »det gør jeg ikke for at begunstige de hjemmetyske børn, men fordi det er det klogeste! Gem endelig din misfornøjelse hos dig selv, indtil vi i aften mødes hos os, så skal du se, at vi i virkeligheden er enige! «

Jeg så nemlig et glimt af det tyskerhad, der $\mathrm{i}$ kamptiden havde været til megen nytte, men som nu ville være en hindring for at vinde hjemmetyskerne tilbage for Danmark, idet kamp som regel møder modkamp, og da vi mødtes om aftenen, sagde jeg straks: $\$ V i$ er sikkert enige om, at en del af genforeningsarbejdet består $i$ at vinde disse dansktalende hjem og børn tilbage, men I fem danske medlemmers ønske ville bidrage til, at der ville blive et tysk hjørne på legepladsen uden for afdelingens afsides liggende to klasser, og skolen ville komme til at mangle den hjelp, som ligger $i$, at disse børn til dato har været en samlet flok, og desuden er det muligt, at den neutrale stilling, de to tyske medlemmer har taget, kan bidrage til arbejdsro om afdelingen - ikke blot ved, at I har givet den en tysk 
uddannet lærer og lærerinde, men også ved at undgå alt, der kan opfattes som en tilsidesættelse! $—$ - Du har vist ret «, svarede han, »det er da altid et forsøg værd! «. Dette bekræftede sig ved, at skolens neutrale stilling hurtigere end ventet vandt den tyske amtsforstanders anerkendelse; thi da vi vanskeligt kunne undvære den tyskuddannede larer til tysk i eksamensskolen, var det nødvendigt at fri ham for gymnastik med de tyske klasser; jeg besluttede så at lade en dansk lærer besørge dette neutrale fag, og for at undgå timespild lod jeg de store drenge $i$ den tyske afdeling fà gymnastik sammen med de store danske folkeskoledrenge. Men dette var en tysk kromand meget misfornøjet med, og hans to store drenge demonstrerede $\mathrm{i}$ timen ved at være ulydige. $\mathrm{Da}$ læreren klagede herover, straffede jeg dem, og dagen efter stod amtsforstanderen på sin trappesten og ventede på mig, da jeg gik hjem fra skole, og spurgte nu, hvorfor jeg lod tyske og danske børn have fælles gymnastiktimer.

»Fordi afdelingen ikke kan undvære sin lærer $\mathrm{i}$ vigtigere fag, end den neutrale gymnastik er, og det kniber hårdt nok endda med at få hans timetal til at slå til «, svarede jeg.

"Godt«, sagde han, »jeg skal ordne den sag!« og således gik det flere gange, antageligt fordi jeg neutralt og dog $\mathrm{i}$ danskhedens interesse gjorde det bedst mulige for afdelingen.

Følgen af det gode forhold til de to tyske medlemmer blev, at hjemmetyske forældre talte med mig, om også deres børn kunne bestå optagelsesprøven til mellemskolen med den skolegang, de havde. $\mathrm{Da}$ jeg kunne henvise til, at de danske børn ikke foreløbig var bedre stillet, faldt de hjemmetyske hjem for fristelsen til at benytte eksamensskolen, og dette blev deres første skridt i dansk retning; der måtte naturligvis fares med lempe ved prøven, og da jeg $\mathrm{i}$ forvejen havde gjort, hvad jeg kunne, for at understrege, at lempelser af hensyn til fortiden gjaldt $i$ alle forhold, gik lærerne velvilligt ind herpå.

$\mathrm{Da}$ det lykkedes for os at undgå det ntyske hjørne« på legepladsen, biev børnene her én stor flok. Derved kunne de danske børns store glæde ved deres skolegang ikke skjules - og jeg har ofte truffet et hjemmetysk barn i fritiden stående uden for en dansk skoleklasses dør og lytte, og med skjult glæde har jeg lukket lytteren indenfor. Følgen blev, at nogle af de hjemmetyske børn smittedes heraf og hjemme bad om at få lov til at komme over i den danske folkeskoleafdeling; 
dermed var overgangen også begyndt her, og i løbet af 2-3 år var de 69 hjemmetyske børn $\mathrm{i}$ afdelingen blevet til 33 .

Rektor Koopmann, der blev sendt til Nordslesvig for at vejlede og værge de oprettede tyske privatskoler, kom of te til Nordborg med det mål for øje at flytte de hjemmetyske børn over $i$ en tysk privatskole, da retten hertil var givet $\mathrm{i}$ den sønderjyske skolelov, men de to nye skolekommissionsmedlemmer, der havde afløst de to bortrejste tyske, ville nødigt oprette en tysk privatskole og bryde den nationale ro, der var opstået $\mathrm{i}$ byen. Omsider fik Koopmann dog sit ønske opfyldt, og de 33, der var tilbage af afdelingen, forlod să kommuneskolen, men de gjorde det næppe med glæde alle; for enkelte af dem kom nogle gange om på deres gamle skoleplads og spiste deres mad i frikvarteret. Sammen med nedgangen viste dette jo tydeligt de svage fødder, tyskheden stod på i Nordborg; thi efter at deres nybygning efter krigen var blevet beslaglagt, har de $\mathrm{i}$ dag [1956] kun få børn tilbage; - rygtet siger seks! Dette vellykkede genforeningsarbejde skyldes naturligvis ikke alene Nordborg, men også hele stillingen på Nordals.

Dermed forlader jeg det hjemmetyske spørgsmål, som nu efter 35 års forløb næsten kun er en saga, og går over til at fortælle om den kamp, der inden et års forløb blev rejst fra dansk side mod de uvante store skoleudgifter af et flertal inden for Nordborg byråd, skønt jeg på det omtalte skatteborgermøde stærkt havde understreget, at skoleudgifterne ville stige betydeligt med den onskede skoleordning.

Når jeg allerede fra første færd frygtede en kommende uro på det økonomiske område, skyldtes dette mit kendskab til, at Nordslesvig i økonomisk henseende havde haft bedre kår bag tyske toldmure og mindre udgifter til fremskridt og sociale formål, end man havde i det gamle land, hvis forhold i så henseende var ukendte for et stort flertal og ikke blev omtalt i den store glæde, som genforeningen var både nord og syd for Kongeåen; først da arbejdsdagen kom, og man stod med skattesedlen $i$ hånden til stat og kommune, og det var en kendsgerning, at den tyske mark $i$ kontanter og papirer blev lig nul, blev mange klar over dette spørgsmål og tabte balancen. Dette var ikke mere mærkværdigt end den underkendelse af Nordslesvigs danskhed, som man kunne møde hist og her i det gamle land af den grund, thi man kunne ikke efter 56 år under Tyskland for- 
lange, at danske forhold skulle passe dem som en handske; man kunne imidlertid have forlangt, at man i Nordborg efter min henstilling skulle have overvejet skoleordningen mere grundigt - også med hensyn til det synkende børneantal år efter år i de kommende ti år, men så sorglost tog man jo herpå, at ikke engang borgmesteren tog afstand fra det almindelige onske $i$ byen og oplandet om, at Nordborg fik et købstadordnet skolevæesen, der også havde en mellemskole med realklasse. Min tilslutning til onsket havde jo kun været betinget af, at man i overgangstiden som skatteborgere ville bestå den prøve, som de øgede skoleudgifter og synet af de uvante små klasser ville være; men dette gik jo desværre for skolen ikke op for mange af skatteborgerne, før de stod med den første skatteseddel $i$ hånden og en tid tabte balancen.

Et flertal $\mathrm{i}$ byrådet krævede nu eksamensskolen nedlagt, men da dette jo ikke kunne ske uden skoledirektionens og Undervisningsministeriets tilladelse, blev der tid til for flere end de »skatteretvendte $\mathrm{i}$ befolkningen at få øje på, hvad deres børn ved tabet af en udvidet undervisning ville miste med hensyn til udbyttet af opholdet på en håndværkerskole, en handelsskole eller en landbrugsskole. Da modstanden talte flere af de folk, man altid havde regnet med, indsendte man foreløbigt ingen ansøgning om nedlæggelsen, men valgte at indføre en sparetid med hensyn til skolen og nægtede $\mathrm{i}$ byrådet flere nodvendige ting blandt andet omlavningen af de store tyske skolestuer, der kunne rumme 50-60 børn, skønt det var en forudsætning, at skolen nu med de mange klasser skulle have flere og helst mindre skolestuer; tillige var det nødvendigt at forny gulvet - hvoraf kun halvdelen kunne bruges! - i slottets gymnastiksal, men et byrådsflertal nægtede begge dele.

Efterhånden som klasseantallet steg, blev det nødvendigt at holde skole de mærkeligste steder, f. eks. på et loftsværelse og i den gamle forfaldne skolebygning fra den danske tid, samt at holde gymnastik i slottets gymnastiksal trods et forfaldent gulv, men lærerne holdt ud med godt humør, og derved opnåede vi, støttet af en god skolekommission, det, vi ville opnå, $i$ stedet for at klage til skoledirektionen; thi efterhånden opdagede byrådsflertallet, at nægtelserne både var uheldige og ulovlige, og derfor foretrak man at komme ud af den grelle stilling ved at bevilge forandringerne.

Der var nu gået 3-4 år, og nu begyndte den nedgang $\mathrm{i}$ børne- 
antallet, som jeg havde forudsagt på skatteborgermødet. Nogle af klasserne begyndte at blive små, og nu forlod man kravet om nedlæggelsen af eksamensskolen - denne fik nu en tvivlsom fred, idet man gik over til at kræve nedlæggelse af nogle af de mange og »dyre " lærerembeder på grund af det synkende børneantal og den okonomisk vanskelige tid.

Denne vej var farligere for den vedtagne skoleordning end den forste, for der var så megen grund under den, at skoledirektionen og Undervisningsministeriet kun vanskeligt kunne afvise den, og hertil kom, at selv om begge disse instanser ville henvise til, at det synkende børneantal var en mulig forbigående følge af krigen, ville der næppe komme noget ud heraf. Der måtte derfor regnes med, at nedlxggelsen af embeder var uundgåelig, og at mellemskolen dermed måtte forsvinde.

En tid arbejdede min tanke med at bevare den ved at slette realklassen, men denne udvej var ikke tilstrækkelig, da kravet ville blive nedlæggelsen af tre embeder, og tilsidst var jeg blevet så træt af arbejdet med at finde en udvej, at jeg opgav håbet om at kunne hjxlpe de mange hjem $\mathrm{i}$ byen og oplandet, der nødigt ville undvære mellemskolen.

Amtsskolekonsulenten, der havde god forståelse af, hvad en mellemskole i Nordborg betød for genforeningsarbejdet $i$ det afsidesliggende Nørherred, besøgte jeg for sidste gang - mente jeg! i den anledning, thi han havde fremdeles kun den trøst til mig, at han, så godt han kunne, ville hjælpe mig med, at jeg fik lov til at beholde de bedst egnede lærere, og dette var naturligvis ikke uden betydning for fremtidens arbejde.

Men da jeg på hjemturen i min gamle Ford-bil kørte gennem Nørherreds landsbyer og med vemod tænkte på, at de mellemskoleelever, vi nu havde fra disse byer, ville blive de sidste, slog pludselig en god idé ned $\mathrm{i}$ mine tanker om at bevare mellemskolen ved kun hvert andet år at optage en ny klasse $i$ den; og ved nxrmere overvejelse så jeg tillige, at en sådan ordning ville bevare skoleordningen af 1920 med undtagelse af, at realeksamen måske måtte forsvinde, men selv hermed var dette efter min mening billigt sluppet. $\mathrm{Nu}$ var det det store spørgsmål, om en så ganske ukendt skoleordning kunne og ville blive godkendt, og for at få dette afgjort rejste jeg den følgende dag i stilhed til Kobenhavn for at forelægge sagen for Under- 
visningsministeriets kontorchef; men han fandt ordningen alt for indviklet, og lidt bittert føjede han til, at det så ud til, at man i Sønderjylland mente at have en vis ret til at få fremmet egne meninger; om han hentydede til, at vi i den første tid havde fäet en forskolelærerinde ansat - uden for loven! - eller havde andre erfaringer i så henseende, blev jeg ikke klar over, men derimod var jeg ikke $i$ tvivl om, at hans svar var ensbetydende med en afvisning trods hans udsagn om, at han ville tænke nærmere over sagen.

Jeg gik så ned til fuldmægtigen, som jeg kendte som meget interesseret $\mathrm{i}$ genforeningsarbejdet fra den tid, jeg var formand for overlærerforeningen for Sønderjylland. Da jeg havde sat ham nærmere ind $i$ sagen, end der var lejlighed til hos hans chef, og mine grunde tiltalte ham, lovede han at gøre sit bedste, hvis sagen kom til nærmere forhandling, og privat meddele mig resultatet, da jeg gjorde ham opmærksom på, at det hastede med at få besked.

En ugestid efter fik jeg så hans private brev, hvori han meddelte, at der ikke var faldet nogen endelig afgørelse endnu, men at hans chef var mildere stemt med hensyn til bevillingen. På dette grundlag satte jeg så skolekommissionen ind $\mathrm{i}$ planen, og medlemmerne var straks villige til at gøre planen til deres plan og tilbyde byrådet at gå med til den onskede nedlxggelse af tre embeder. Dette blev så ordningen, da den omsider blev godkendt af skoledirektion og ministerium, og dermed var både mellemskolen og skoleordningen af 1920 reddet til bedre tider, - til glxde i mange hjem både $i$ byen og oplandet, og jeg kan den dag i dag møde taknemmelighed for min overgangsplan, når jeg gæster Nordborg.

$\mathrm{Da}$ jeg i 1920 som overlærer rykkede ind i Nordborg kommuneskole, skete dette jo ikke - som omtalt - , fordi jeg ønskede at forlade grænseskolearbejdet, som både min kone og jeg havde haft så megen glæde af, men det var mig en ikke ringe trøst, at det nye arbejde lå på sønderjysk grund og midt $\mathrm{i}$ befolkningen. Jeg vidste jo, at der var nok at gøre, og lad mig straks sige, at jeg blev lige så glad ved dette - noget forandrede - arbejde, som jeg havde været ved grænseskolearbejdet, thi her var nok, der kaldte - i første rxkke en tysk afdeling på hele 69 børn $\mathrm{i}$ det danske Nordborg; dette tal måtte bringes ned, og så mange som muligt af hjem og børn vindes tilbage for Danmark, og dette måtte skolen derfor indstilles på. 
Dernæst måtte den danske befolkning vindes for den danske skoleform og tankegangen på dette område, thi begge var meget forskellige fra det, sønderjyderne forlod i 1864, der - når jeg undtager det nationale - $\mathrm{i}$ høj grad lignede den skole, tyskerne bød dem, og der var ingen forandringer sket heri lige til 1920. I 56 år havde sønderjyderne altså været uden for den danske skoleform, og hvad tankegangen angår, kunne man ikke forlange, at det brede lag af befolkningen skulle have lært at kende noget til denne gennem ungdommens ophold på de danske grænseskoler og højskoler, da disse uvilkårligt blev betragtet som skoler for den konfirmerede ungdom.

Man måtte altså med tålmodighed vente på en ret stor forandring - lidt efter lidt - $i$ den sønderjyske opfattelse af børneskolen, og herom vidner da også en skrivelse til mig fra borgmesteren og et flertal $\mathrm{i}$ byrådet med krav om en omhyggeligere undervisning i religion og krav om flere timer $\mathrm{i}$ tysk $\mathrm{i}$ folkeskolen; - $x$ ldste klasse havde fire! - Dette forlangende havde jeg ondt ved at finde mening $i$, men misfornøjelsen med religionsundervisningen var der mere naturlig grund under - dels $\mathrm{i}$ børnenes hjemmelektier heri uden udenadlærte skriftsteder, dels $i$, at den tyskuddannede præst, som Nordborg beholdt, ganske naturligt måtte finde, at det stod dårligt til med skolens religionsundervisning ud fra den beskedne plads, vi havde givet det udenadlærte $i$ alle fag, i Grundtvigs og Kolds fædreland. Hertil kom, at forældrene måtte få samme indtryk, når konfirmanderne ofte ikke fik lejlighed til at svare med egne ord, men skulle, som tilfældet var $i$ den tyske tid, kunne benytte et udenadlært skriftsted som svar.

Det var de store forskelle, der er på, om man lægger hovedvægten på udenadlært lærdom eller på personlig påvirkning, som her stødte sammen, thi forståelsen heraf manglede i det mindste hos de fleste forældre.

Her lå en ny og stor opgave. - I den tyske tid var påvirkning $i$ skolen næsten umulig; thi når læreren forsøgte at nå ind til hjertelivet hos børnene, var den nationale modsætning en hindring ifølge forældrenes - og dermed også ifølge børnenes - forhold til den tyske skole.

De tyskuddannede lærere var of te gode til at "lære fra sig«, dette lærte jeg at sætte stor pris på hos den tyske lærer, vi beholdt 
i 1920 , da han lige som flere af dem gerne ville tjene den danske skole, men de nåede ikke alle at blive fortrolige med den danske skoles inderste væsen og mål: den personlige påvirkning!

Denne side af undervisningen måtte der skaffes forståelse for hos forældrene, og hertil fik skolen efter et årstids forløb en udmærket hjælp $\mathrm{i}$ en forskolelærerinde $\mathrm{i}$ de to yngste klasser. Børnene gjorde gode fremskridt $i$ skolefagene, og efterhånden opdagede forældrene tillige, at der var kommet noget nyt til, som de ikke kendte fra deres skoletid, nemlig at deres børn, når de kom hjem, var glad optaget af deres skoledag og af, hvad frk. Hansen havde sagt eller fortalt for dem. Dermed stod forældrene $i$ virkeligheden ansigt til ansigt med begrebet påvirkning, og hvad der kan udrettes ad den vej.

Jeg er derfor ikke i tvivl om, at frk. Hansen og hendes småbørn var de første, der jævnede et lille stykke af vejen til en bedre skoleopfattelse end den, man havde fra den tyske tid, og hendes historie bør jeg derfor fortælle.

Ved starten af Nordborg skole benyttede jeg den almindelige skik at lade klasselærerne hente deres klasse i 1 . folkeskoleklasse, men da flere af lærerne var ukendte med undervisningen af småbørn, og det første forsøg ikke faldt tilfredsstillende ud, måtte jeg mindes den forskolelærerinde, som i Hejls havde undervist mine børn, og tiltrods for, at loven forbed ansættelsen af forskolelærerinder ved købstadordnede skoler, besluttede jeg dog at forsøge på at få tilladelse hertil, da der just skulle ansættes en ny lærerinde ved skolen, og drog for egen regning til København.

Departementschefen hørte med et smil på min beretning om de udmærkede forudsætninger, som forskolelærerinderne kunne møde med i småbørnsklasserne både med hensyn til undervisning og omgang, men da jeg var kommet så vidt, afbrød han mig med at sige: "Véd De ikke, at loven er over os alle, - også over mig!« "Jo, det véd jeg «, svarede jeg, »men jeg kommer fra Sønderjylland, og til hjælp $\mathrm{i}$ genforeningsarbejdet er intet for godt! $\mathrm{Og}$ det viste sig senere, at denne bemærkning ikke var uden virkning, for han gav mig efter en samtale det løfte at ville overveje sagen, når skolekommissionen indsendte en ansøgning om tilladelsen.

$\mathrm{Da}$ jeg havde forklaret skolekommissionen mit syn på en forskolelærerinde, når det gjaldt de yngste klasser, var de villige til at 
indsende en ansøgning, og resultatet blev, at frk. Hansen havnede i Nordborg - trods lovens forbud!

$\mathrm{Nu}$ er hun fyldt de 70 og har fået sin afsked og det med honnør, for næsten den ganske by samledes for at sige hende tak. Dette fortxller tillige, at den danske skoleform har sejret i sønderjysk tankegang - naturligvis også takket være flere af mine gode medhjælpere og deriblandt ikke mindst vor udmærkede historielærer.

Jeg havde naturligvis fået indbydelse til at være med ved festen, men en overstået operation hindrede mig dengang $i$ at gøre den lange rejse fra Bagsværd til Nordborg, og jeg prøvede så på at sige hende tak gennem en sang; og nynner man melodien samtidigt med, at man læser sangen, og har hørt sønderjyder synge så fuldttonende, som de kan gøre det, så er det måske også muligt at mærke lidt af den stærke stemning $\mathrm{i}$ den store forsamling og forstå, at der bag stemningen ligger en forandring $i$ den sønderjyske skoleopfattelse. - Frk. Hansen skrev til mig, at hun græd af glæde over sangen og stemningen, for hun forstod at værdsæette begge dele som ægte - også den sejr, der var vundet.

For at man kan komme indholdet $\mathrm{i}$ festen nærmere, gengiver jeg her sangen, som jeg havde ladet trykke i mange eksemplarer.

Melodi: "Højt fra treets gronne topa.

Mødre glade med de små gik til Nordborg skole, hjemme var det så som så uden Per og Ole, men $\mathrm{p} a ̊$ forhånd vidste de, Per og Ole kunne pli lære hos jubilaren hele, hele skaren.

Thi bag trøstens milde ord lå en sikker spore til umage mere stor, end de for sig gjorde. Skaberglæden vokste frem, lytterglæden kom til dem. Vågne blev de alle, Stine, Søren, Palle!
Jubilaren var jo kendt som en mor for flokken, og det var jo aldrig hændt, at hun brugte stokken. Alt sig formed' som en leg. kappelysten dagligt steg, ingen tabte modet, om de ej forstod -et $\kappa$.

Hele hemm'ligheden ved frk. Hansens virke rummes $i$ personlighed, skolen blev en kirke, hvor de små fik lært at tro, »ja< og nej* betyder jo $i$ vor ganske færden noget her $i$ verden. 


\section{Derfor siger jeg tilsidst tak på manges vegne! men isar dog ganske vist sker det her på egne. Tak for alt, hvad De har gjort for at hjalpe lektien bort fra det tvungne dode til et liv $i$ grode.}

Mel.: „Dansken bar sejr vundet .
Dansken har sejr vundet med Dem - med Dem.
De tog de små ved hånden, og de gik frem, og hos de store piger De vandt en plads, så de med glæde siger med mig - hurra!

Denne lille festsang er jo som alt mit arbejde stærkt i familie med Kolds og Grundtvigs skolesyn, og dette gav anledning til, at enkelte folk i skolekredsen, der stod uden for det, man kalder wet både og", fik det indtryk af mig som skolemand, at jeg savnede respekt for det faglige skolearbejde. Dette tillader jeg mig at berigtige, for jeg kan med god samvittighed sige, at jeg aldrig har glemt at lægge vægt på den faglige side af undervisningen, - hverken $i$ folkeskolen eller eksamensafdelingen; herom vidner da også en årelang og bitter strid med en lærer $i$ dansk og en mindre bitter strid med en lærer $i$ regning, for den slags indlader en overlærer sig vistnok sjældent på, hvis det står småt til med hans interesse for den faglige side; og med hensyn til den undervisning, jeg selv gav, skal jeg tillade mig at anfore et vidnesbyrd, en landskendt censor en gang gav mig:

Han begyndte sit brev med at takke for god modtagelse og skriver derefter: "Så kom eksamen i dansk, som jeg meget godt husker som en af de bedste, jeg har været med til, en af de eksaminer, som er censors fryd, fordi eksaminationen er fast, redelig og uden disse kedelige paradenumre, der altid på mig har virket - stik imod hensigten - som kunstig tåge, der skulle dxkke manglende viden eller måske navnlig - umodenhed og manglende forståelse«. 


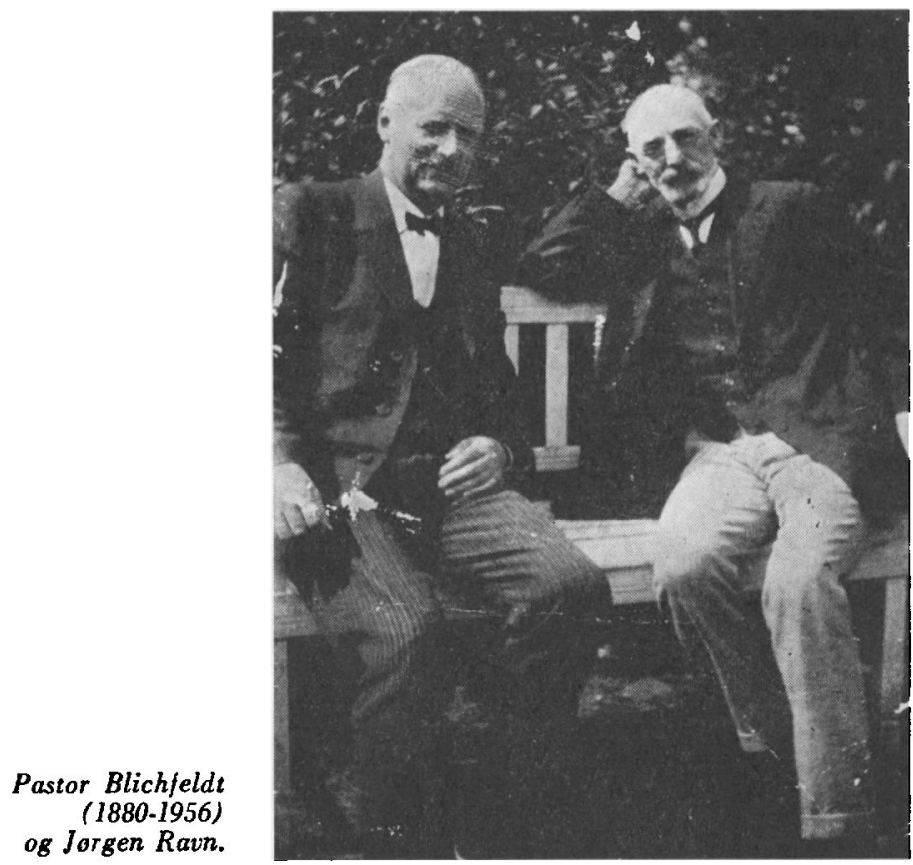

Noget lignende har han - lektor Mielche - sikkert skrevet i den indberetning, han skulle indgive efter sin censorrejse.

Hermed forlader jeg min omtale af genforeningsarbejdet inden for skolen, og det er mit håb, at det nogenlunde tydeligt fremgår, at hovedsagen for mig ikke har været at fortælle, hvad sønderjyderne manglede på dette område efter 56 års udlændighed, men derimod klart at vise, at danskheden var gået så velbevaret ud af den mangeårige kamp, at den danske skole endnu passede deres børn, og at den danske skoleform - væsentligt skabt $\mathrm{i}$ disse 56 år - formåede at vinde deres forældres forstålse; thi deri ligger den egentlige grund til den sejr, den danske skole så hurtigt vandt.

Noget lignende kan siges om kirkearbejdet omkring Nordborg og omegn, takket være den danske præst - pastor Blichfeldt - i Oksbøl.

Til en begyndelse var det almindeligt, at man i det brede lag mente, at de danske præster ikke kunne måle sig med de tyske "der var for lidt præst i dem«, syntes man, og desuden talte de tyske 
præster jo dansk i kirken. Man savnede deres højtidelige væremåde både på prædikestolen og $\mathrm{i}$ omgangen med befolkningen. I Oksbøl var præsten død, så der var ingen vej uden om kaldelsen af en dansk præst, men i Nordborg kunne et flertal af menigheden bevare den tyske prest, endda med et meget stort flertal, skønt det tyske folketal kun var lille.

Det varede derfor ikke længe, før vi danske embedsmænd og enkelte sønderjyder - deriblandt $\mathrm{H}$. P. Hanssens gode ven Nis Nissen og flere - fandt vej ud til Oksbøl kirke. At man forlod sin egen kirke for at søge en anden, var noget ukendt i Nørherred og vakte derfor forargelse både $\mathrm{i}$ Nordborg og Oksbøl.

I Nordborg foreslog et byrådsmedlem at forbyde mig som overlærer at give et dårligt eksempel ved at søge til en anden kirke, men flertallet var dog klar over, at der var religionsfrihed i Danmark. Ude i Oksbøl syntes mange, at vi udenbysfolk virkede forstyrrende ved vor nærværelse, men efter et årstids forløb blev man lidt efter lidt klar over, at vi ikke kom af protestgrunde, men at vi havde glæde af deres præst. Vi kom jo hver søndag, og dette bidrog til, at vi kom på talefod med Oksbøl-folkene, ja, endogså på vennefod med enkelte, og vi glemte aldrig den gode tid, vi havde i Oksbøl kirke; for samtidigt var pastor Blichfeldt da også - både som præst og menneske - groet så fast $i$ sognet, at man nødigt ville undvære ham, og da man i Nordborg gennem årene efterhånden havde lart ham at kende, sendte man i 1943 bud efter ham, da embedet blev ledigt, og dette hjalp ganske godt på kirkegangen dér. - Nu var man altså kommet så vidt, at man kunne undvære den tyske højtidelighed hos en præst.

"Nørherredhus «, - det store forsamlingshus i Nordborg, - samlede fremdeles efter 1920 Nørherreds befolkning til møder med fuldt hus omkring de dxkkede kaffeborde, når aftenen bød på en fremmed taler eller sangforeningens gode sang. Men først og fremmest samledes man i mindet om sammenholdet $\mathrm{i}$ den tyske tid med dens mangfoldighed af urimelige krav og handlinger, som man da var ude for.

Ordet var ved de fleste lejligheder frit ved kaffebordet, og forsamlingen havde fra kamptiden mange gode talere, - ikke mindst P. Grau, Pøl - og vi embedsmænd, som var kommet nordfra, glxdede os også ved den kraft og varme, hvormed man sang vore gode 


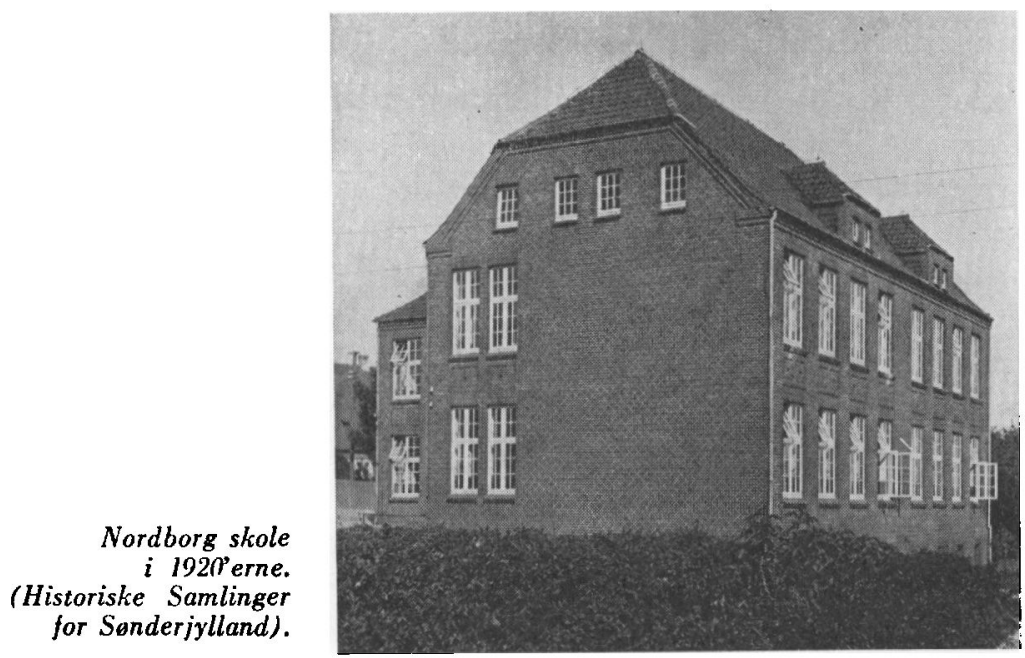

danske sange; her kunne de kongerigske forsamlinger, som vi var vante til, ikke stå mål, - men i længden bliver jo det, at man overvejende lever på minder, det samme som stilstand i udviklingen, for nu havde sønderjyderne jo fuldtud fælles tilværelse med det gamle land i stort og småt. Der var nok, der trængte til belysning; dette gjaldt skatter og de danske meget omfattende sociale forhold efter udviklingen i det sidste slægtled, og det gjaldt sognets indflydelse med hensyn til skole- og kirkeforhold.

$\mathrm{Nu}$ er det jo nok muligt, at det var os, der var kommet nordfra, der først rørte ved dette forhold, men det skete med stor forsigtighed, og adskillige sønderjyder, som havde fulgt lidt med i forholdene i Danmark, rørte da også den samme streng; men mange havde nok i Konkordie-aftenerne og frygtede, at vort mål var at forvandle denne forening til en ren og skær foredragsforening. For dem var P. Grau den egentlige fører, og en klog kriger, som han var, optrådte han aldrig offentligt $i$ dette spørgsmål, men ad privat vej forstod han som få at gøre sig gxldende; thi han var næppe uden del $i$, at Nordborg i 1920 ikke fik en danskuddannet præst, og at sognet ved et stort flertal beholdt sin tyskuddannede præst.

En rig sønderjysk født grosserer havde købt Nordborg slot for at sætte sig et minde derovre, f. eks. ved her at oprette et alderdoms- 
hjem, men det endte med, at han overlod slottet til Danmarks sønderjyske foreninger til brug som grænseskole i stedet for som påtænkt at bygge en ny ved Kruså. Imidlertid forbeholdt grossereren sig en sommerlejlighed på slottet og indflydelse sammen med foreningernes skoleudvalg, f. eks. ved valg af forstander; da P. Grau nød stor anerkendelse $\mathrm{i}$ København, har grossereren sikkert ved valget rådført sig med ham som boende $i$ sognet, og P. Grau har nxppe mellem ansøgerne ønsket at anbefale en mand som $f$. eks. lignede mig. Det forstanderpar, som takket være skoleudvalgets taknemmelighed fik pladsen, passede i alt fald P. Grau godt, men viste sig hurtigt uskikket til stillingen, og elevantallet sank efter de første hold år efter år.

En skønne dag stod grossereren i min stue med de ord: "Jeg kommer for at give Dem en undskyldning, fordi jeg ikke har hilst på Dem før, og fordi jeg ikke har spurgt Dem som gammel grænseskoleforstander før valget, thi nu trænger vi til Deres hjælp, hvis De er villig hertil; thi med den nuvarende ledelse går det ikke i længden! « Dette gjorde jeg naturligvis gerne, især da jeg anede, at det gamle skoleudvalg fra Hejls stod bag henvendelsen, og jeg fandt da også omsider et rigtigt forstanderpar, der som unge i sin tid havde været ansat ved Vester Vedsted grænseskole; nu sad han - Overgaard hed han - som lærer på Sydals, og det viste sig hurtigt, at dette forstanderpar egnede sig for arbejdet. Den store bygning fik fuldt hus, og fra den tid var den gamle grosserer såre venligt indstillet over for mig, mens $P$. Grau syntes at glide noget $i$ baggrunden. - Da Overgaard døde, sørgede Jefsen Christensen for, at et så anset og dygtigt forstanderpar som Demuth og hans kone blev valgt.

Et bestyrelsesmedlem af Sønderjyllands "Historiske Samfund har opfordret mig til også at fortælle noget om kendte folk i Nordborg, f. eks. Nis Nissen, borgmester Petersen o. s. v., og dette ønske vil jeg gerne imødekomme, så godt jeg kan.

En mand som Nis Nissen skulle gerne gå over i de kommende slxgters verden, men min tabte hukommelse hindrer mig $i$ at benytte enkeltheder fra de mange lejligheder, hvorved han var hovedmanden, og efter mange overvejelser har jeg besluttet at gengive mit manuskript til den tale, jeg holdt for ham på hans 80 års fødselsdag, da den giver et omfattende billede af hans person og hans betydning:

"Tak for indbydelsen! - Det er altid rart at være med, når du 


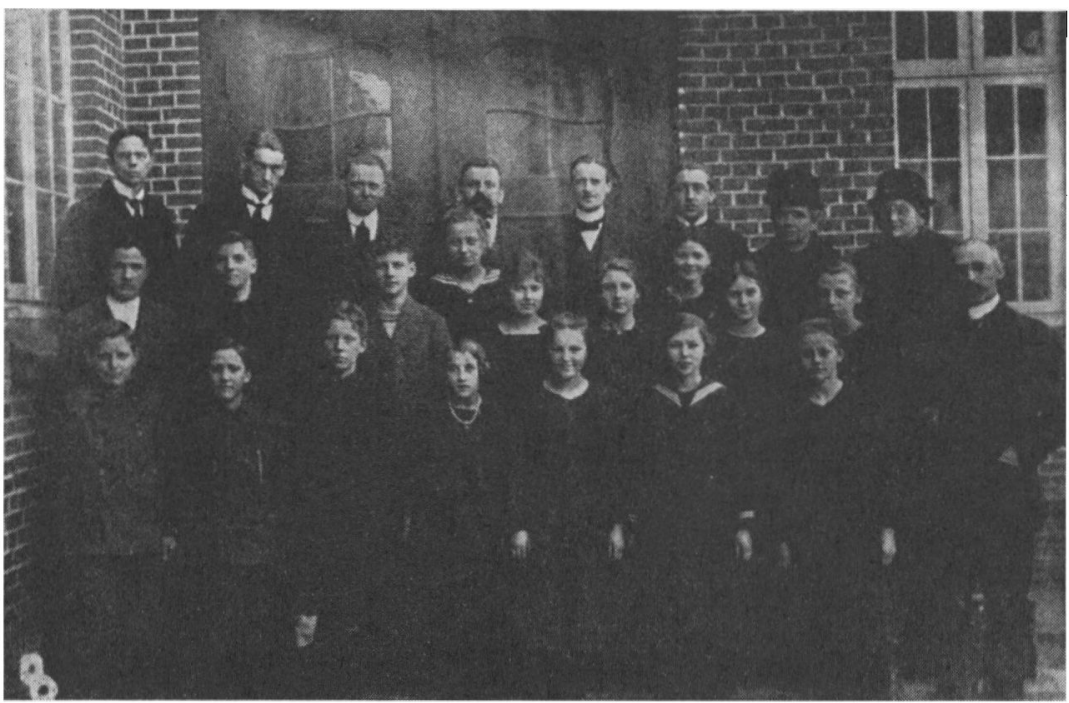

Gruppebillede af elever og larere fra $1920^{\prime}$ erne umiddelbart efter genforeningen. I bageste rakke fra venstre ses larer S. D. Wolff, larer Johannes Bogner, larer Chresten Frederiksen (Svenstrup), larer Ejnar Kaae, larer Chresten Hansen-Christensen, larer Hans Berthelsen Dixen, larerinde fru Astrid Juel-Frederiksen, larerinde frk. Borg. I 2. rakke fra venstre ses Arne Friedrichsen, nuvarende overlarer J. Christiansen, Nicolai Frederiksen, Dorothea Jorgensen, Nany Hansen, Sophie Nicolaisen, Helga Skov, Mimi Petersen, Gunder Hansen, overlarer Jorgen Henriksen Raun. I forreste rakke fra venstre ses Jens Dominicussen, Mads Frederiksen, Nis Rasmussen, Corelia Petersen, Thyra Bladt, Thyra Bonde og Nana Jorgensen.

samler dine venner, og ikke mindst $\mathrm{i}$ aften, da du har samlet os om din 80 års dag.

På en sådan aften følger det af sig selv, at vi må se tilbage ikke blot over dit eget liv, men også til de kår, hvorunder dit slægtled har levet; - det var en mørk tid med håbløshed inden for mangen god dansk mands dor; der var jo hverken vej eller sti at øjne ud af disse kår, og det er vanskeligt at forstå, at der blev arbejdsmod tilbage, og at dette mod lidt efter lidt voksede $i$ omfang og styrke, takket være dig og ligesindede.

Hvad var det da, der bar dit slægtled igennem denne mørke tid? - endda således, at dette slægtled står med en egen glans over sig! - Der er dem, der vil svare, at det var de tyske myndigheders hensynsløse færd, der æggede jer til vågen og bitter modstand, og dette gjaldt måske ikke så få - hvem har f. eks. ikke moret sig over hjuler Jefsens evne til at drille og vildlede tyskerne; men til 
syvende og sidst var det dog ikke tyskernes fremfærd alene, der skabte den dansk-bevidste ungdom, der i tusindvis i 1914 samledes om H. P. Hanssens talerstol i Haderslev, thi den ungdom var jo fremgået af dit slægtleds længsel efter dansk folke- og åndsliv, der gav sig udslag $i$, at man sendte ungdommen på efterskoler og højskoler $\mathrm{i}$ det gamle land og rejste danske forsamlingshuse rundt om i Nordslesvig.

Det var denne dybe længsel efter danske kår, der bandt dig og H. P. Hanssen sammen for hele livet, thi han var jo ikke blot en klog politiker, men også en mand, der søgte næring for sit liv i et dansk folkeliv, vor digtning, vor lovgivning og vor historie.

Var jeg maler, Nis Nissen, ville det friste mig til at male dig og H. P. Hanssen stående på en sønderjysk bakke og se over grænsen ind til jert gamle land, thi dette var $i$ sandhed jeres længslers land.

Således er H. P. Hanssen gået over $\mathrm{i}$ historien, og således vil du gå over $\mathrm{i}$ Nordborgs historie, thi $\mathrm{i}$ dig har Als givet sit store bidrag til danskhedens sejr både før og efter genforeningen, og officielt har du gjort det som sekretær i Vælgerforeningen, som medlem af synoden og fællessynoden $i$ den tyske tid og kom derved officielt med ind $\mathrm{i}$ kampen for danske religionstimer $\mathrm{i}$ den fortyskede børneskole, og efter genforeningen fik du sæde $\mathrm{i}$ det sønderjyske salmebogsudvalg, og jeg véd, at biskop Ammundsen hurtigt lærte at regne med din viden og kristendomsopfattelse.

For alt dette skal der lyde en varm tak til dig på din 80 års fødselsdag!«

Gårdejer Solmer var mere talende end Nis Nissen og altid parat til at slå et åbent slag for forståelsen af en god sag, der $i$ overgangstiden skulle eller burde fremmes i Danmarks navn, og han gjorde det som regel rigtigt og godt, men også her mangler jeg eksempler.

Borgmester Petersen, som oprindelig var farver, manglede $i$ høj grad i sin nye stilling det kendskab, som hans broder i Tønder, bagermester Thorvald Petersen, og Nis Nissen på forhånd havde til danske forhold, og dette medførte som allerede omtalt vanskeligheder for skolen, skønt han var en god dansk mand $i$ den forstand, at han altid var en sikker mand ved danske møder.

Peter Graus store betydning $\mathrm{i}$ den tyske tid har jeg undladt at omtale, da den er velkendt, men derimod har jeg i enkelte forhold rørt ved hans begrænsede forståelse af den vanskelige overgangstid, 

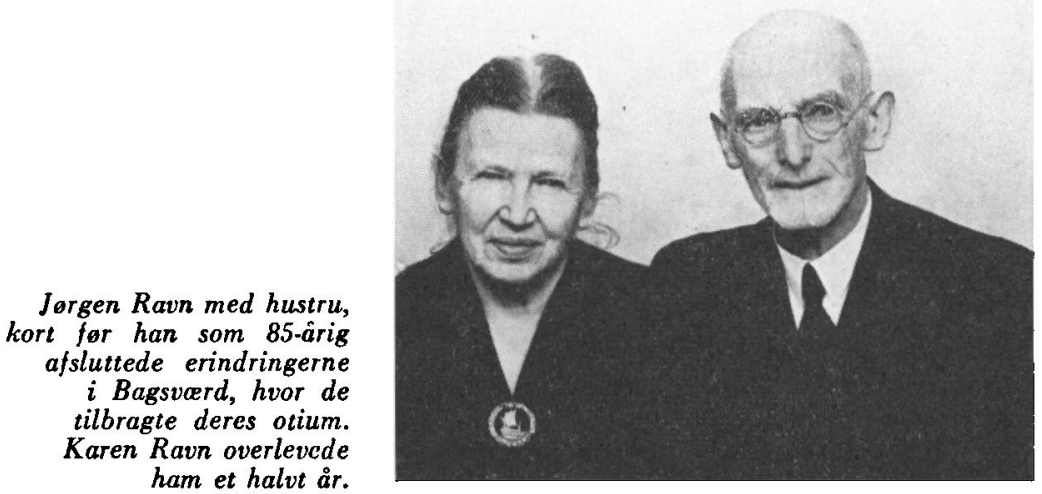

og denne stilling havde efter min mening sin grund $i$, at han først og fremmest var »slesviger «. Skulle jeg male ham, måtte han stå i kongeriget med ansigtet vendt mod syd til en dansk granse ved Ejderen; for et samlet Slesvig var overvejende hans længslers land, og derfor måtte kravet om atter at få, hvad der var gammelt dansk land, ikke forsvinde i Nordslesvig, f. eks. ved, at dette spørgsmål sov glemt hen $i$ en glad og omfattende forbindelse med moderlandet.

Her står vi over for Peter Graus store betydning for det sydslesvigske spørgsmål i dag; men mindre fremsynet var han i genforeningsarbejdet i Nordslesvig på flere punkter, og i økonomisk henseende var han - $i$ alt fald en tid - en åben modstander af de skatteforhold, der fulgte med genforeningen, og blev derved en stotte for den daværende opposition.

Efter 1928 fulgte der for mig 13 fredelige og fremdeles glxdelige år, inden jeg blev 70 og fik min afsked; thi udgangen af den otteårige skolestrid blev god, idet den skabte tilfredshed i begge lejre, da skoleudgifterne blev mindre ved embedsnedlaggelserne, og det dog var lykkedes at bevare mellemskolen og realklassen, til børneantallet blev normalt.

Fra 1938 havde jeg endvidere den glæde, at man ved tilbygning udvidede skolen, så den fik et skolekøkken, et sløjdlokale, et godt lærerværelse samt to nye skolestuer. Glæden blev ikke mindre ved, at springet var gjort fra en begyndelse, hvori vi havde holdt skole de mærkeligste steder, og jeg tænker med tak på, at lærerpersonalet tålmodigt fandt sig heri. Kort sagt: jeg synes, jeg på mine gamle dage har lov at huse den følelse, at Nordborg blev mit andet Hejls. 